\title{
LEVEL II SCOUR ANALYSIS FOR BRIDGE 4 (MNTGTH00020004) on TOWN HIGHWAY 2, crossing WADE BROOK, MONTGOMERY, VERMONT
}

U.S. Geological Survey Open-File Report 96-561

Prepared in cooperation with

VERMONT AGENCY OF TRANSPORTATION and

FEDERAL HIGHWAY ADMINISTRATION 


\section{LEVEL II SCOUR ANALYSIS FOR BRIDGE 4 (MNTGTH00020004) on TOWN HIGHWAY 2, crossing WADE BROOK, MONTGOMERY, VERMONT}

By Erick M. Boehmler

U.S. Geological Survey Open-File Report 96-561

Prepared in cooperation with

VERMONT AGENCY OF TRANSPORTATION and

FEDERAL HIGHWAY ADMINISTRATION 


\title{
U.S. DEPARTMENT OF THE INTERIOR BRUCE BABBITT, Secretary
}

\author{
U.S. GEOLOGICAL SURVEY \\ Gordon P. Eaton, Director
}

For additional information write to:

District Chief

U.S. Geological Survey 361 Commerce Way

Pembroke, NH 03275-3718
Copies of this report may be purchased from:

U.S. Geological Survey Earth Science Information Center Open-File Reports Section Box 25286, MS 517 Federal Center

Denver, CO 80225 


\section{CONTENTS}

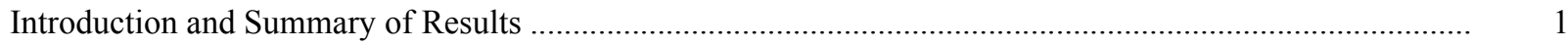

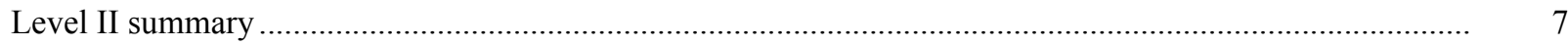

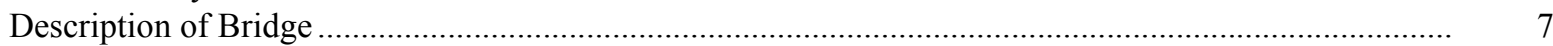

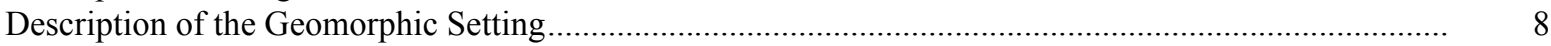

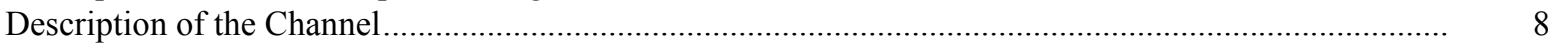

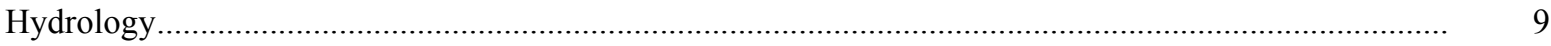

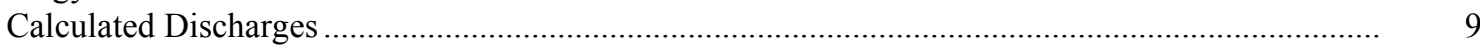

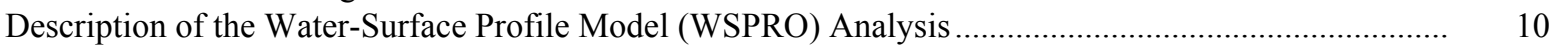

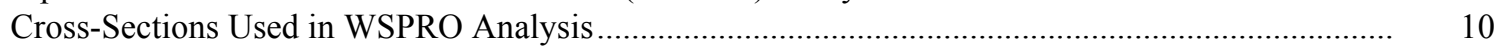

Data and Assumptions Used in WSPRO Model ...................................................................... 11

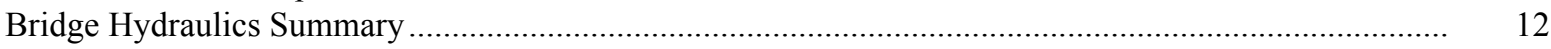

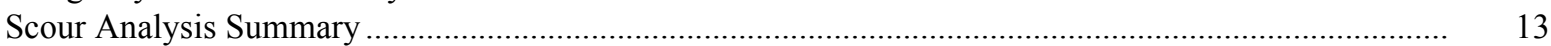

Special Conditions or Assumptions Made in Scour Analysis ...................................................... 13

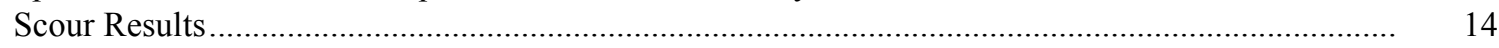

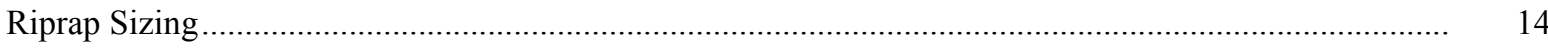

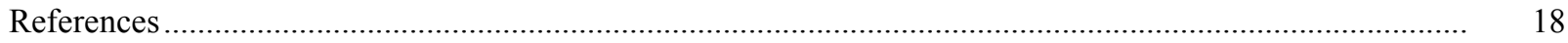

Appendixes:

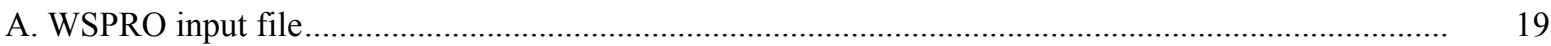

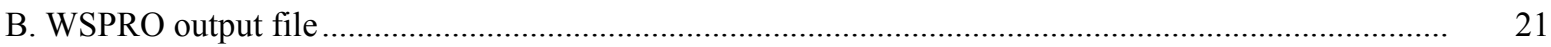

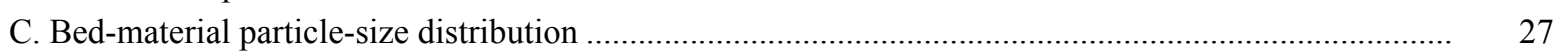

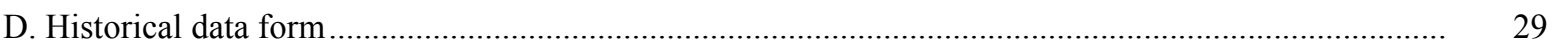

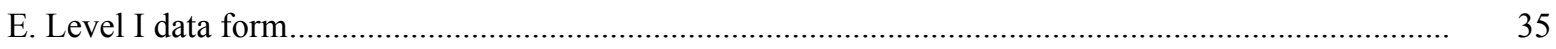

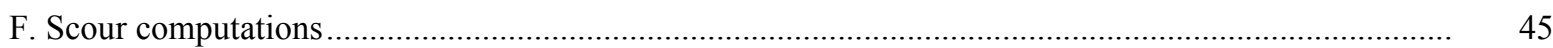

\section{FIGURES}

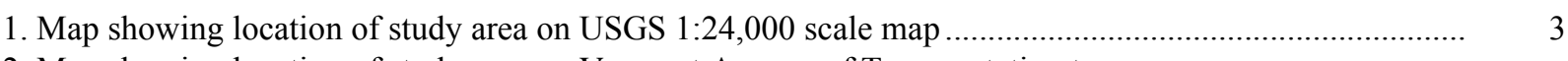

2. Map showing location of study area on Vermont Agency of Transportation town
highway map

3. Structure MNTGTH00020004 viewed from upstream (November 8, 1994) ........................................... 5

4. Downstream channel viewed from structure MNTGTH00020004 (November 8, 1994)........................ 5

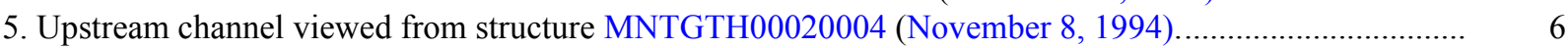

6. Structure MNTGTH00020004 viewed from downstream (November 8, 1994). .................................... 6

7. Water-surface profiles for the 100- and 500-year discharges at structure

MNTGTH00020004 on Town Highway 2, crossing Wade Brook,

Montgomery, Vermont.

8. Scour elevations for the 100- and 500-year discharges at structure

MNTGTH00020004 on Town Highway 2, crossing Wade Brook,

Montgomery, Vermont.

\section{TABLES}

1. Remaining footing/pile depth at abutments for the 100-year discharge at structure MNTGTH00020004 on Town Highway 2, crossing Wade Brook,

Montgomery, Vermont.

2. Remaining footing/pile depth at abutments for the 500-year discharge at structure

MNTGTH00020004 on Town Highway 2, crossing Wade Brook,

Montgomery, Vermont.

5
15 


\begin{tabular}{|c|c|c|}
\hline Multiply & By & To obtain \\
\hline \multicolumn{3}{|c|}{ Length } \\
\hline inch (in.) & 25.4 & millimeter (mm) \\
\hline foot $(\mathrm{ft})$ & 0.3048 & $\operatorname{meter}(\mathrm{m})$ \\
\hline mile (mi) & 1.609 & kilometer (km) \\
\hline \multicolumn{3}{|c|}{ Slope } \\
\hline foot per mile ( $\mathrm{ft} / \mathrm{mi})$ & 0.1894 & meter per kilometer $(\mathrm{m} / \mathrm{km})$ \\
\hline \multicolumn{3}{|c|}{ Area } \\
\hline square mile $\left(\mathrm{mi}^{2}\right)$ & 2.590 & square kilometer $\left(\mathrm{km}^{2}\right)$ \\
\hline \multicolumn{3}{|c|}{ Volume } \\
\hline cubic foot $\left(\mathrm{ft}^{3}\right)$ & $\begin{array}{l}0.02832 \\
\text { Velocity and Flow }\end{array}$ & cubic meter $\left(\mathrm{m}^{3}\right)$ \\
\hline foot per second $(\mathrm{ft} / \mathrm{s})$ & 0.3048 & meter per second $(\mathrm{m} / \mathrm{s})$ \\
\hline cubic foot per second $\left(\mathrm{ft}^{3} / \mathrm{s}\right)$ & 0.02832 & cubic meter per second $\left(\mathrm{m}^{3} / \mathrm{s}\right)$ \\
\hline $\begin{array}{l}\text { cubic foot per second per } \\
\text { square mile } \\
{\left[\left(\mathrm{ft}^{3} / \mathrm{s}\right) / \mathrm{mi}^{2}\right]}\end{array}$ & 0.01093 & $\begin{array}{l}\text { cubic meter per } \\
\text { second per square } \\
\text { kilometer }\left[\left(\mathrm{m}^{3} / \mathrm{s}\right) / \mathrm{km}^{2}\right]\end{array}$ \\
\hline
\end{tabular}

OTHER ABBREVIATIONS

$\begin{array}{lrlr}\mathrm{BF} & \text { bank full } & \text { LWW } & \text { left wingwall } \\ \mathrm{cfs} & \text { cubic feet per second } & \text { MC } & \text { main channel } \\ \mathrm{D}_{50} & \text { median diameter of bed material } & \text { RAB } & \text { right abutment } \\ \mathrm{DS} & \text { downstream } & \text { RABUT } & \text { face of right abutment } \\ \mathrm{elev} & \text { elevation } & \text { RB } & \text { right bank } \\ \mathrm{f} / \mathrm{p} & \text { flood plain } & \text { ROB } & \text { right overbank } \\ \mathrm{ft} & \text { square feet } & \text { RWW } & \text { right wingwall } \\ \mathrm{ft} / \mathrm{ft} & \text { feet per foot } & \text { TH } & \text { town highway } \\ \mathrm{JCT} & \text { junction } & \text { UB } & \text { under bridge } \\ \mathrm{LAB} & \text { left abutment } & \text { US } & \text { upstream } \\ \mathrm{LABUT} & \text { face of left abutment } & \text { USGS } & \text { United States Geological Survey } \\ \text { LB } & \text { left bank } & \text { VTAOT Vermont Agency of Transportation } \\ \text { LOB } & \text { left overbank } & \text { WSPRO } & \text { water-surface profile model }\end{array}$

In this report, the words "right" and "left" refer to directions that would be reported by an observer facing downstream. Sea level: In this report, "sea level" refers to the National Geodetic Vertical Datum of 1929-- a geodetic datum derived from a general adjustment of the first-order level nets of the United States and Canada, formerly called Sea Level Datum of 1929.

In the appendices, the above abbreviations may be combined. For example, USLB would represent upstream left bank. 


\title{
LEVEL II SCOUR ANALYSIS FOR BRIDGE 4 (MNTGTH00020004) ON TOWN HIGHWAY 2, CROSSING WADE BROOK, MONTGOMERY, VERMONT
}

\author{
By Erick M. Boehmler
}

\section{INTRODUCTION AND SUMMARY OF RESULTS}

This report provides the results of a detailed Level II analysis of scour potential at structure MNTGTH00020004 on town highway 2 crossing Wade Brook, Montgomery, Vermont (figures 1-8). A Level II study is a basic engineering analysis of the site, including a quantitative analysis of stream stability and scour (U.S. Department of Transportation, 1993). A Level I study is included in Appendix E of this report. A Level I study provides a qualitative geomorphic characterization of the study site. Information on the bridge, gleaned from VTAOT files, was compiled prior to conducting Level I and Level II analyses and can be found in Appendix D.

The site is in the Green Mountain physiographic province of north-central Vermont in the town of Montgomery. The $1.68-\mathrm{mi}^{2}$ drainage area is in a predominantly rural and forested basin. In the vicinity of the study site, the banks have woody vegetation coverage.

In the study area, Wade Brook has an incised, sinuous channel with a slope of approximately $0.0454 \mathrm{ft} / \mathrm{ft}$, an average channel top width of $30 \mathrm{ft}$ and an average channel depth of $2 \mathrm{ft}$. The predominant channel bed materials are gravel and cobbles $\left(\mathrm{D}_{50}\right.$ is 77.7 $\mathrm{mm}$ or $0.255 \mathrm{ft}$ ). The geomorphic assessment at the time of the Level I and Level II site visit on November 8, 1994, indicated that the reach was degraded. There were no scour holes observed during the Level I assessment. However, general streambed lowering was evident as both abutments were undermined equally with no localized scour on one abutment over the other.

The town highway 2 crossing of Wade Brook is a 23-ft-long, two-lane bridge consisting of one 20-foot concrete slab span (Vermont Agency of Transportation, written communication, August 3,1994$)$. The bridge is supported by vertical, concrete abutments with wingwalls. The channel is skewed approximately 30 degrees to the opening while the computed opening-skew-to-roadway is 25 degrees.

The scour protection measures at the site were type-1 stone fill (less than 12 inches diameter) on the upstream right wingwall and all road approach embankments, type-2 stone fill (less than 36 inches diameter) on the left abutment, and a "laid-up" stone wall at the 
upstream end of the upstream left wingwall and in front of the upstream left bank. Additional details describing conditions at the site are included in the Level II Summary and Appendices D and E.

Scour depths and rock rip-rap sizes were computed using the general guidelines described in Hydraulic Engineering Circular 18 (Richardson and others, 1995).

Total scour at a highway crossing is comprised of three components: 1) long-term streambed degradation; 2) contraction scour (due to accelerated flow caused by a reduction in flow area at a bridge) and; 3 ) local scour (caused by accelerated flow around piers and abutments). Total scour is the sum of the three components. Equations are available to compute depths for contraction and local scour and a summary of the results of these computations follows.

Contraction scour for all modelled flows was $0.1 \mathrm{ft}$. The worst-case contraction scour occurred at the 100-year and 500-year discharges. Abutment scour ranged from 3.9 to $5.2 \mathrm{ft}$. The worst-case abutment scour also occurred at the 500-year discharge. Additional information on scour depths and depths to armoring are included in the section titled "Scour Results". Scoured-streambed elevations, based on the calculated scour depths, are presented in tables 1 and 2. A cross-section of the scour computed at the bridge is presented in figure 8. Scour depths were calculated assuming an infinite depth of erosive material and a homogeneous particle-size distribution.

It is generally accepted that the Froehlich equation (abutment scour) gives "excessively conservative estimates of scour depths" (Richardson and others, 1995, p. 47). Many factors, including historical performance during flood events, the geomorphic assessment, scour protection measures, and the results of the hydraulic analyses, must be considered to properly assess the validity of abutment scour results. Therefore, scour depths adopted by VTAOT may differ from the computed values documented herein, based on the consideration of additional contributing factors and experienced engineering judgement. 


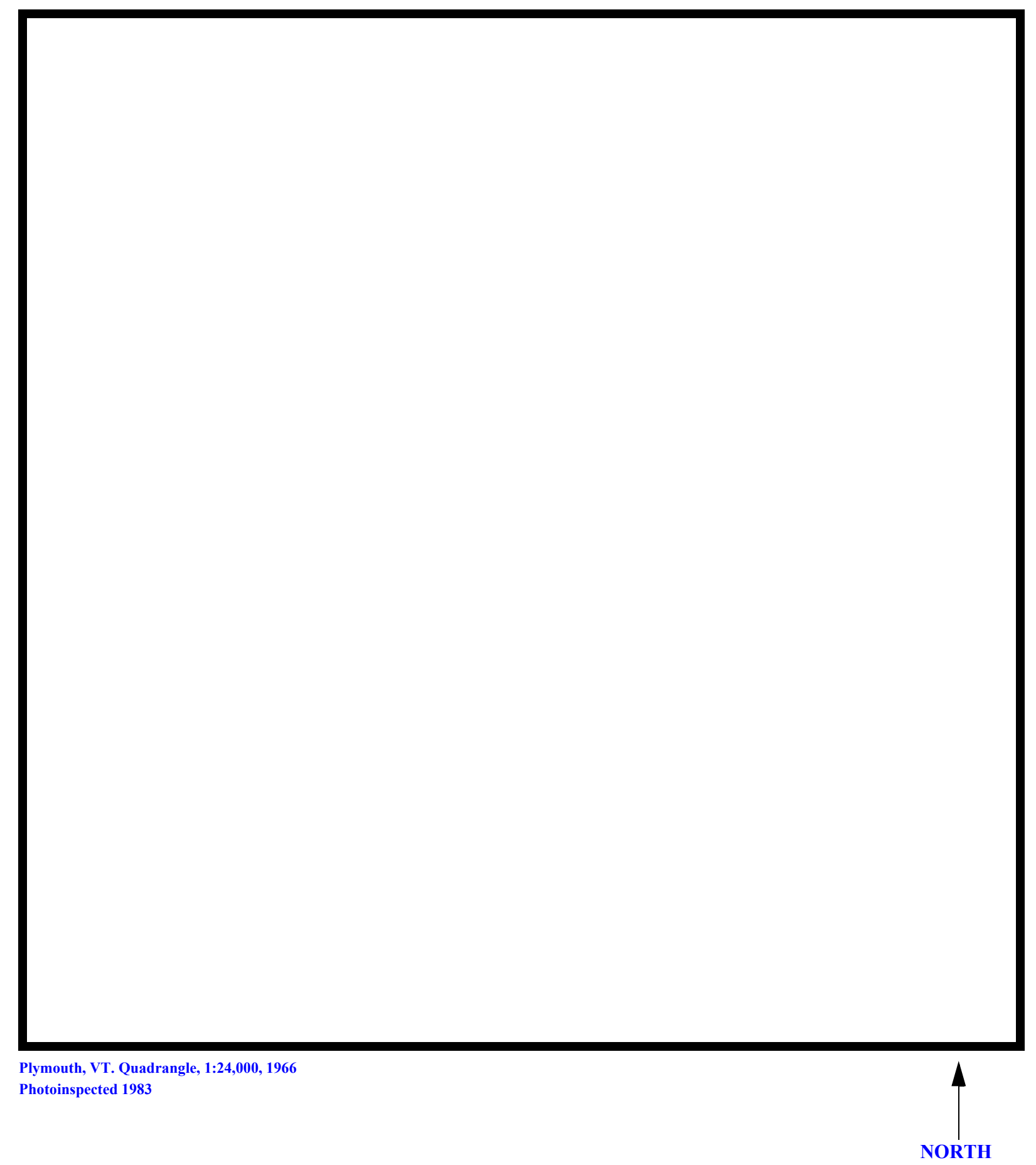

Figure 1. Location of study area on USGS 1:24,000 scale map. 
Figure 2. Location of study area on Vermont Agency of Transportation town highway map. 

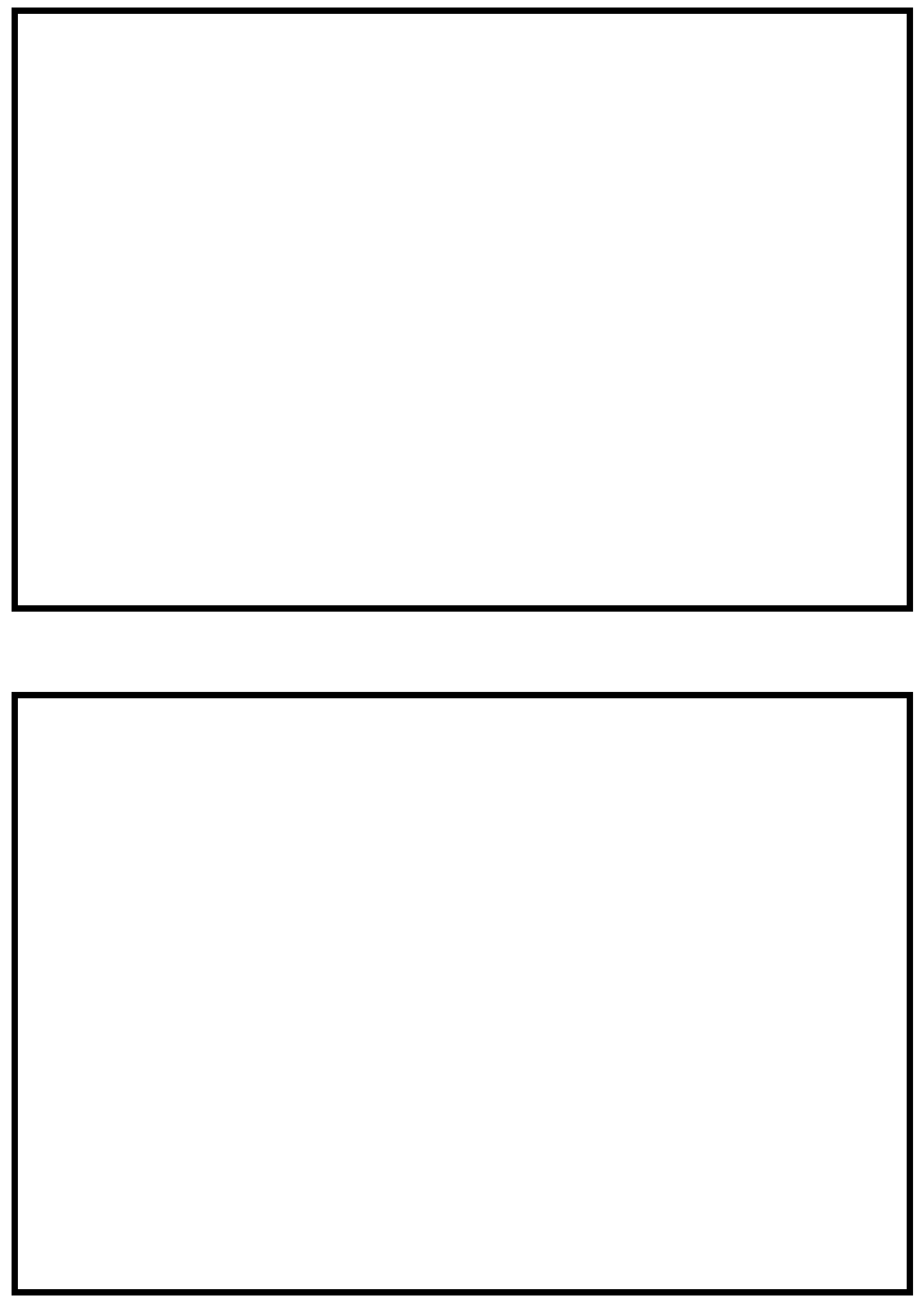

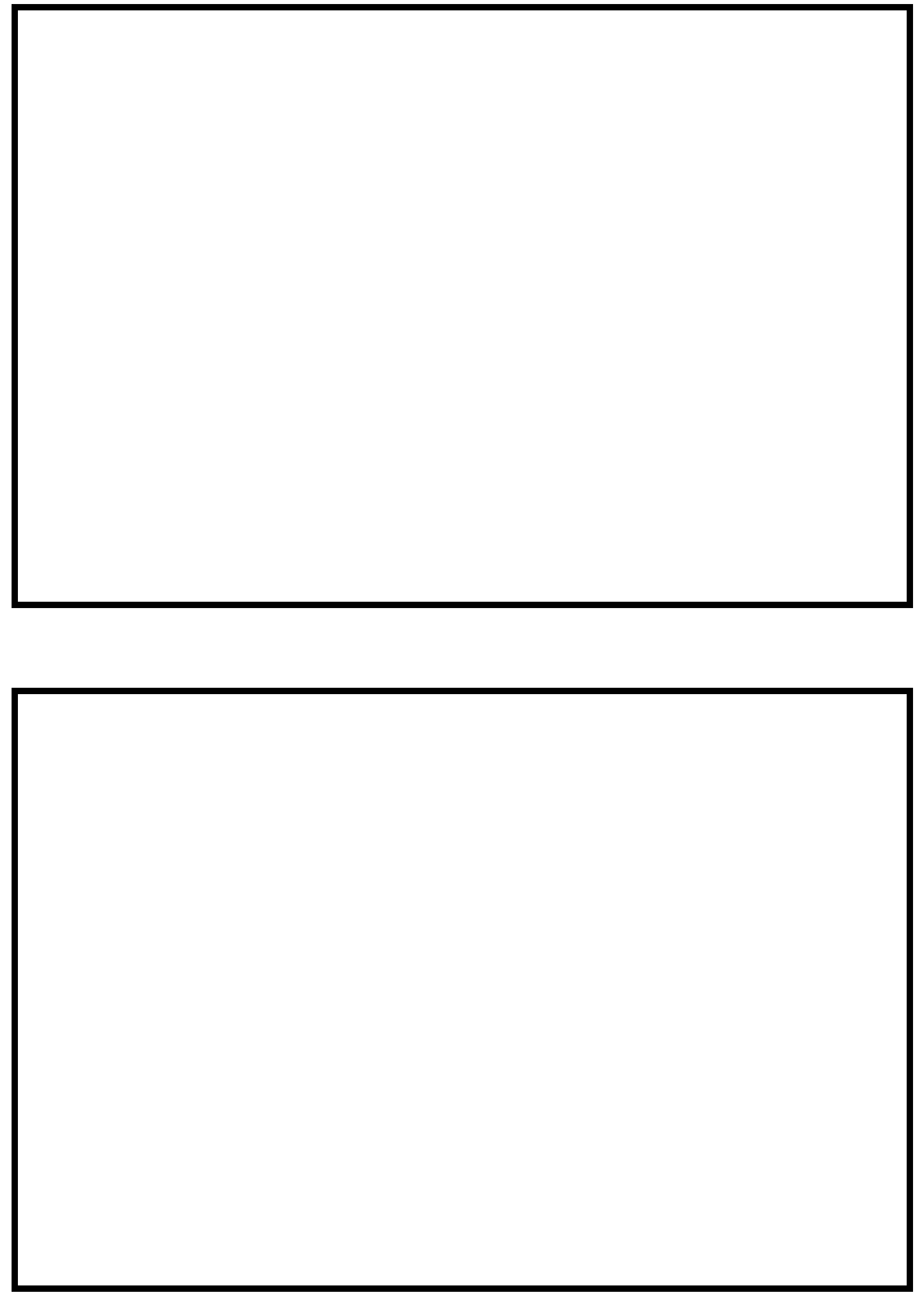


\section{LEVEL II SUMMARY}

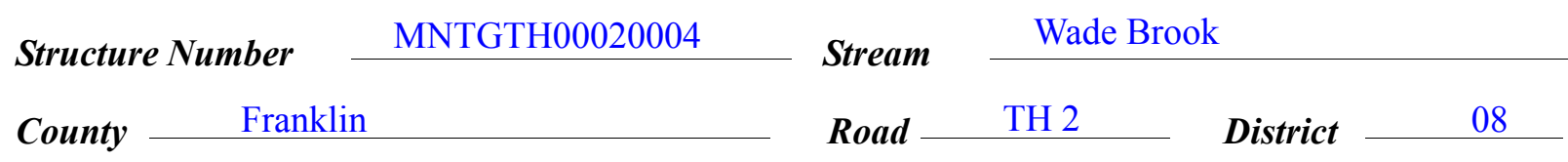

\section{Description of Bridge}

Bridge length $\stackrel{23}{ } \quad \boldsymbol{f t} \quad$ Bridge width $\stackrel{26.0}{f t}$ Max span length $\stackrel{20}{\boldsymbol{f t}}$ Alignment of bridge to road (on curve or straight)

Vertical

Abutment type

Stone fill on abutment?

\section{Embankment type}

Drto af incnortion
Sloping

$11 / 08 / 94$

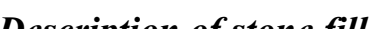
Type-1, on all road approach embankments and the upstream right wingwall and a "laid-up" stone wall on the upstream left bank to the upstream end of the upstream left wingwall.

Abutments and wingwalls are concrete.

$\cdots$

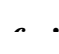

\section{Y}

Is bridge skewed to flood flow according to Y ' survey? Angle

30

Is bridge skewed to flood flow according to Y ' survey? Angle

There is a moderate channel bend in the upstream reach.

Debris accumulation on bridge at time of Level I or Level II site visit:

\begin{tabular}{|c|c|c|}
\hline $\begin{array}{c}\text { Date of insnortion } \\
11 / 08 / 94 \\
\end{array}$ & $\begin{array}{l}\text { Percent of alsmnal } \\
\text { bloeked inortzontatly }\end{array}$ & $\begin{array}{l}\text { Percent of } 0 \\
\text { blocked verticatty }\end{array}$ \\
\hline & & 0 \\
\hline
\end{tabular}

Level II Moderate. There is some debris scattered around the channel but no significant accumulation in any one location.

Potential for debris

None evident on 11/08/94.

Dosriho anv, fonturos noar ar at tho hridoo that mav affort flow, (includo ahsorvation dato) 


\section{Description of the Geomorphic Setting}

General topography The channel is located within a narrow, high relief valley setting, with little to no flood plain and steep valley walls on both sides.

Geomorphic conditions at bridge site: downstream (DS), upstream (US)

Date of inspection $\quad 11 / 08 / 94$

DS left: $\quad$ Steep channel bank to TH 2 roadway and valley wall.

DS right: $\quad$ Steep channel bank to a narrow flood plain and valley wall.

US left: $\quad$ Steep channel bank to a narrow flood plain and valley wall.

US right: $\quad$ Steep channel bank to valley wall.

\section{Description of the Channel}

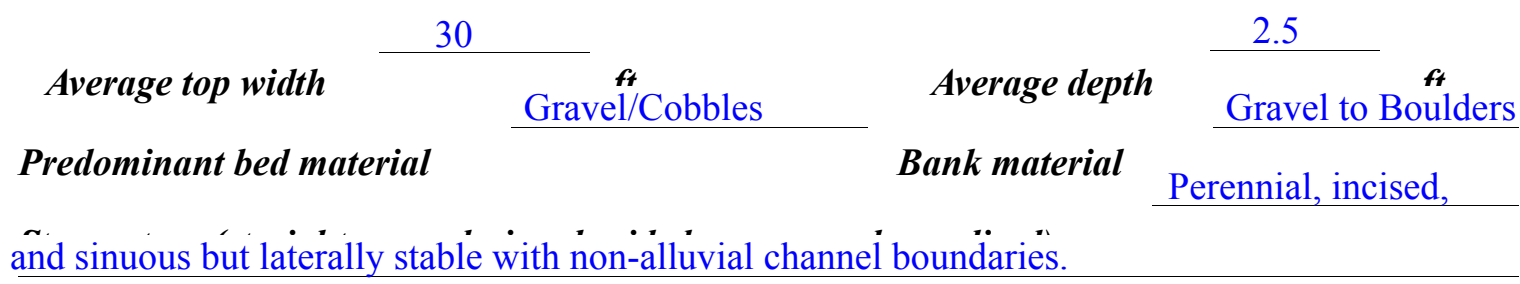

Vegetative co 1 Town highway 2 roadway surface and forest.

DS left: $\quad$ Forest.

DS right: $\quad$ Forest.

US left: $\quad$ Forest.

US right: $\quad$ Y

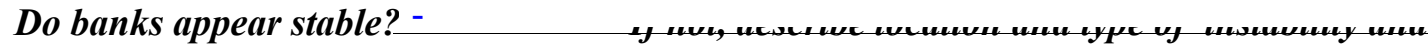

date of observatton.

None evident on

$11 / 08 / 94$.

Describe any obstructions in channel and date of observation. 


\title{
Hydrology
}

Drainage area $\frac{1.68}{\boldsymbol{m i}^{2}}$

Percentage of drainage area in physiographic provinces: (approximate)

Physiographic province

Green Mountain
Percent of drainage area

100

\begin{abstract}
Is drainage area considered rural or urban?
Rural urbanization: None

Describe any significant
\end{abstract}

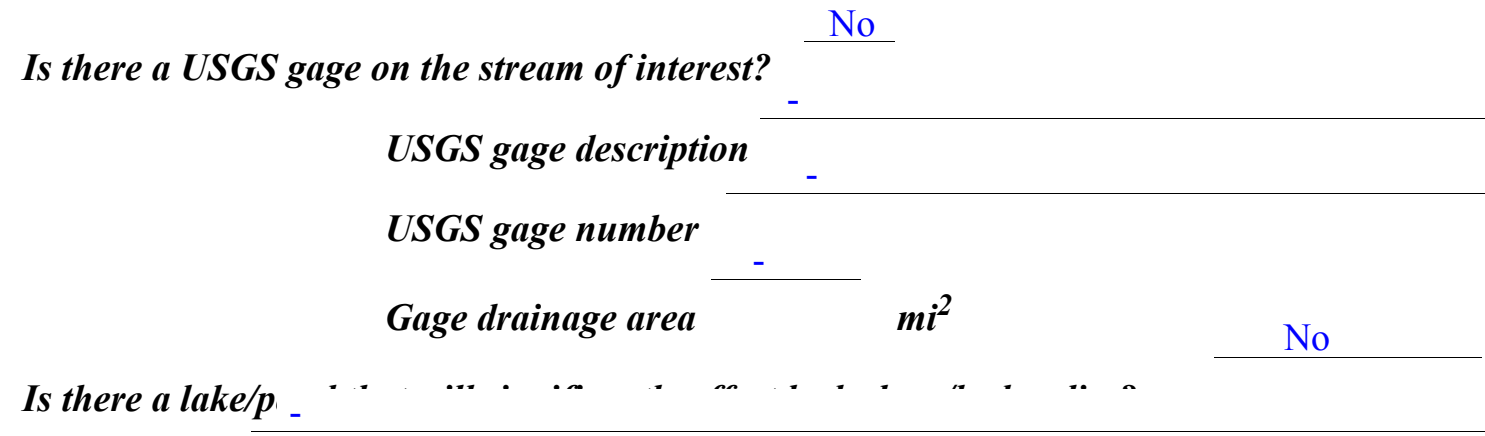

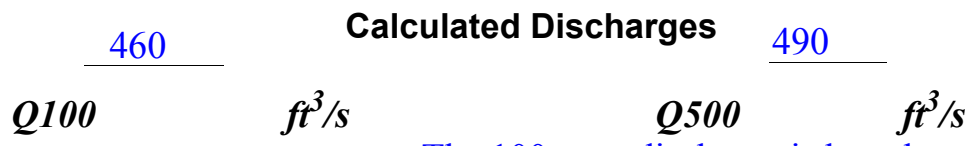

The 100-year discharge is based on the results of

several empirical relationships (FHWA, 1983; Johnson and Tasker, 1974; Potter 1957a\&b; and

Talbot, 1887). The flood frequency curves for each empirical relationship were extrapolated and the 500-year discharge applied was based on the extrapolated curve estimates from each relationship. 


\section{Description of the Water-Surface Profile Model (WSPRO) Analysis}

Datum for WSPRO analysis (USGS survey, sea level, VTAOT plans)

USGS survey

Datum tie between USGS survey and VTAOT plans

None

Description of reference marks used to determine USGS datum. $\quad$ RM1 is the center point

of a chiseled "X" on top of the DS end of the right abutment: elev. $496.02 \mathrm{ft}$, arbitrary survey

datum. RM2 is the center point of a chiseled "X" on top of a boulder located approximately 30

feet upstream on the left bank side of the channel: elev. $497.72 \mathrm{ft}$, arbitrary survey datum.

\section{Cross-Sections Used in WSPRO Analysis}

\begin{tabular}{cccl}
\hline ICross-section & $\begin{array}{c}\text { Section } \\
\text { Reference } \\
\text { Distance } \\
\text { (SRD) } \text { in feet }\end{array}$ & $\begin{array}{c}{ }^{2} \text { Cross-section } \\
\text { development }\end{array}$ & \multicolumn{1}{c}{ Comments } \\
\hline EXITX & -19 & 1 & $\begin{array}{l}\text { Exit section } \\
\text { Downstream Full-valley } \\
\text { section (Templated from } \\
\text { EXITX) }\end{array}$ \\
BRIDG & 0 & 2 & $\begin{array}{l}\text { Bridge section } \\
\text { Road Grade section }\end{array}$ \\
RDWAY & 15 & 1 & $\begin{array}{l}\text { Modelled Approach sec- } \\
\text { tion (Templated from } \\
\text { APPRO }\end{array}$ \\
& 46 & 1 & $\begin{array}{l}\text { APTEM) } \\
\text { Approach section as sur- } \\
\text { veyed (Used as a tem- } \\
\text { plate) }\end{array}$ \\
\hline
\end{tabular}

${ }^{1}$ For location of cross-sections see plan-view sketch included with Level I field form, Appendix E. For more detail on how cross-sections were developed see WSPRO input file. 


\section{Data and Assumptions Used in WSPRO Model}

Hydraulic analyses of the reach were done by use of the Federal Highway Administration's WSPRO step-backwater computer program (Shearman and others, 1986, and Shearman, 1990). The analyses reported herein reflect conditions existing at the site at the time of the study. Furthermore, in the development of the model it was necessary to assume no accumulation of debris or ice at the site. Results of the hydraulic model are presented in the Bridge Hydraulic Summary, Appendix B, and figure 7.

Channel roughness factors (Manning's " $\mathrm{n}$ ") used in the hydraulic model were estimated using field inspections at each cross section following the general guidelines described by Arcement, Jr. and Schneider (1989). Final adjustments to the values were made during the modelling of the reach. Channel " $\mathrm{n}$ " values for the reach ranged from 0.055 to 0.065 , and the overbank " $n$ " value applied was 0.035 .

Normal depth at the exit section (EXITX) was assumed as the starting water surface. This depth was computed by use of the slope-conveyance method outlined in the user's manual for WSPRO (Shearman, 1990). The slope used was $0.0454 \mathrm{ft} / \mathrm{ft}$ which was estimated from the topographic map (U.S. Geological Survey, 1986).

The surveyed approach section (APTEM) was moved along the approach channel slope $(0.0680 \mathrm{ft} / \mathrm{ft})$ to establish the modelled approach section (APPRO), one bridge length upstream of the upstream face as recommended by Shearman and others (1986). This approach also provides a consistent method for determining scour variables.

For the 100- and 500-year discharge, WSPRO assumes critical depth at the at the bridge section. Supercritical models were developed for these discharges. Analyzing both the supercritical and subcritical profiles for each discharge, the results indicate that the water surface profile passes through critical depth within the bridge opening. Thus, the assumptions of critical depth at the bridge are satisfactory solutions. 


\section{Bridge Hydraulics Summary}

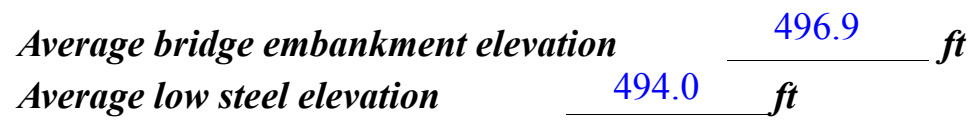

100-year discharge $\quad 460 \quad \mathrm{ft}^{3} / \mathrm{s}$

Water-surface elevation in bridge opening $\quad 490.4 \quad f t$

Road overtopping? ___ N Discharge over road __ _ $\quad$ _. s

\begin{tabular}{llll} 
Area of flow in bridge opening & $49 \quad \boldsymbol{f t}^{2}$ \\
\cline { 2 - 3 } Average velocity in bridge opening & 9.5 & $\mathrm{ft} / \mathrm{s}$
\end{tabular}

Maximum WSPRO tube velocity at bridge $11.4 \mathrm{ft} / \mathrm{s}$

Water-surface elevation at Approach section with bridge 493.1

Water-surface elevation at Approach section without bridge $\quad 492.5$

Amount of backwater caused by bridge $\quad 0.6 \quad$ it

500-year discharge $\quad 490 \quad \boldsymbol{f t}^{3} / \mathrm{s}$

Water-surface elevation in bridge opening

Road overtopping? ___ N Discharge over road ___

Area of flow in bridge opening $\quad 51 \quad \mathrm{ft}^{2}$

Average velocity in bridge opening $\quad 9.7 \mathrm{ft} / \mathrm{s}$

Maximum WSPRO tube velocity at bridge 11.8 's

Water-surface elevation at Approach section with bridge 493.3

Water-surface elevation at Approach section without bridge $\quad 492.6$

Amount of backwater caused by bridge 0.7 .

Incipient overtopping discharge ___ _ $\mathrm{ft}^{3} / \mathrm{s}$

Water-surface elevation in bridge opening $\quad-\quad t_{t}$

Area of flow in bridge opening _ _ _ $\mathrm{ft}^{2}$

Average velocity in bridge opening __ $\quad \mathrm{ft}_{\mathrm{s}}$

Maximum WSPRO tube velocity at bridge $\quad-\quad f t / s$

Water-surface elevation at Approach section with bridge

Water-surface elevation at Approach section without bridge

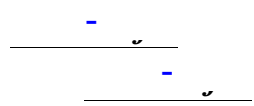

Amount of backwater caused by bridge _ _ _ it 


\section{Scour Analysis Summary}

\section{Special Conditions or Assumptions Made in Scour Analysis}

Scour depths were computed using the general guidelines described in Hydraulic Engineering Circular 18 (Richardson and others, 1995). Scour depths were calculated assuming an infinite depth of erosive material and a homogeneous particle-size distribution. The results of the scour analysis are presented in tables 1 and 2 and a graph of the scour depths is presented in figure 8 .

Contraction scour was computed by use of the clear-water contraction scour equation (Richardson and others, 1995, p. 32, equation 20) for the 100-year and 500-year discharges. For contraction scour computations, the average depth in the contracted section (AREA/ TOPWIDTH) is subtracted from the depth of flow computed by the scour equation (Y2) to determine the actual amount of scour.

Abutment scour for each modeled discharge was computed by use of the Froehlich equation (Richardson and others, 1995, p. 48, equation 28). Variables for the Froehlich equation include the Froude number of the flow approaching the embankments, the length of the embankment blocking flow, and the depth of flow approaching the embankment less any roadway overtopping.

The length to depth ratio of the embankment blocking flow exceeded 25 for the 100year discharge at both abutments. Although the HIRE equation (Richardson and others, 1993 , p. 50, equation 25) generally is applicable when this ratio exceeds 25 , the results from the HIRE equation were not used. Hydraulic Engineering Circular 18 recommends that the field conditions be similar to those from which the HIRE equation was derived (Richardson and others, 1993). Since the equation was developed from Army Corp. of Engineers' data obtained for spurs dikes in the Mississippi River, the HIRE equation was not adopted for the narrow, incised, upland valley at this site. 


\section{Scour Results}

\section{0-yr discharge 500-yr discharge}

Contraction scour:

(Scour depths in feet)

Main channel

Live-bed scour

Clear-water scour

Depth to armoring

Left overbank

Right overbank

Local scour:

Abutment scour

Left abutment

4.3

5.2

3.9-

$4.0-$

Right abutment

Pier scour

Pier 1

Pier 2

Pier 3

\section{Abutments:}

Left abutment

Right abutment

Piers:

Pier 1

Pier 2

\section{Riprap Sizing}

Incipient overtopping 100-yr discharge 500-yrdischarge discharge

1.2

1.2

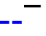

$--$

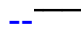
(D $D_{50}$ in feet)

overtopping discharge

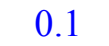

$13.0^{-}$

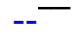

$--$

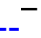

$--$

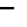




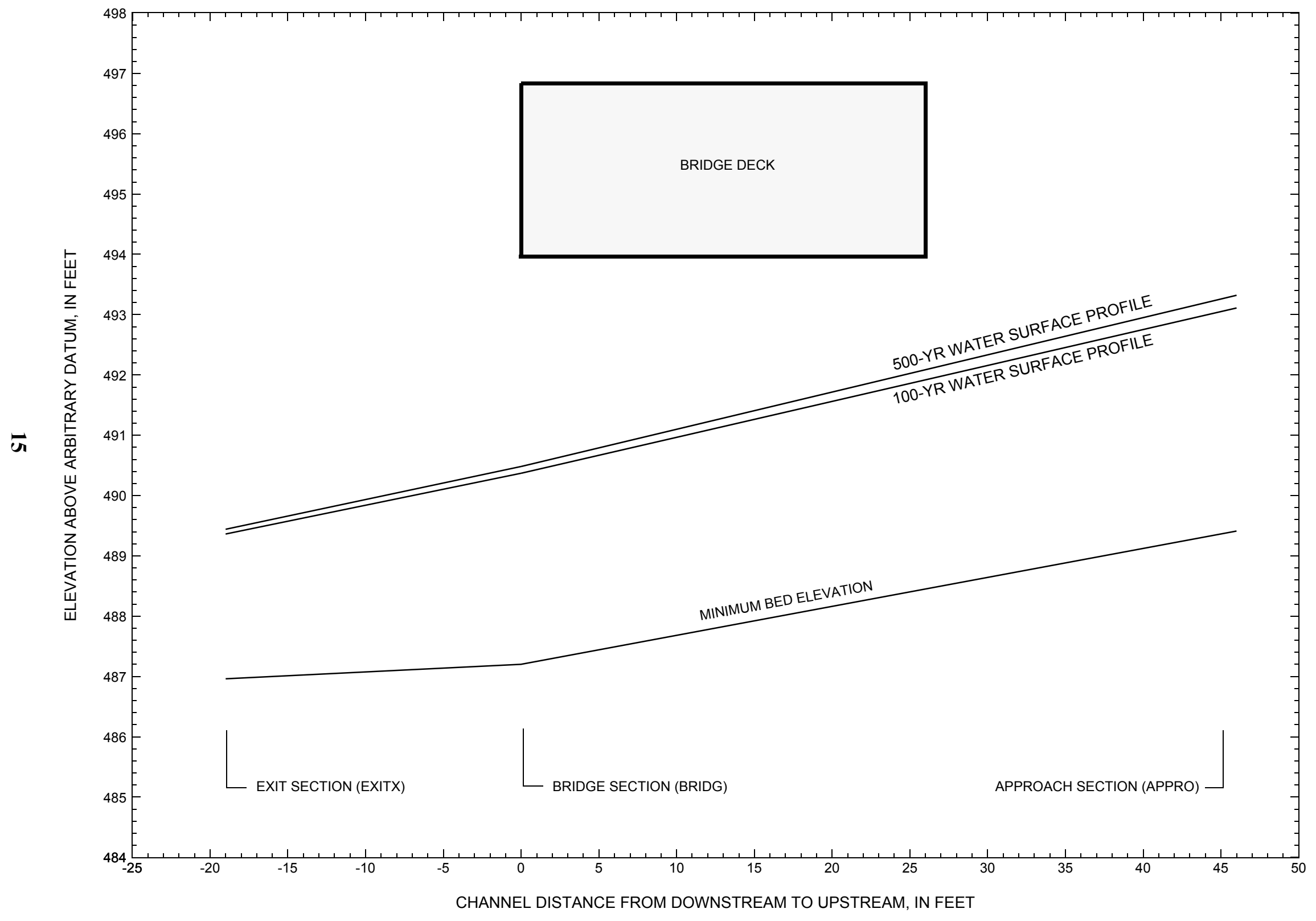

Figure 7. Water-surface profiles for the 100- and 500-yr discharges at structure MNTGTH00020004 on town highway 2, crossing Wade Brook, Montgomery, Vermont. 


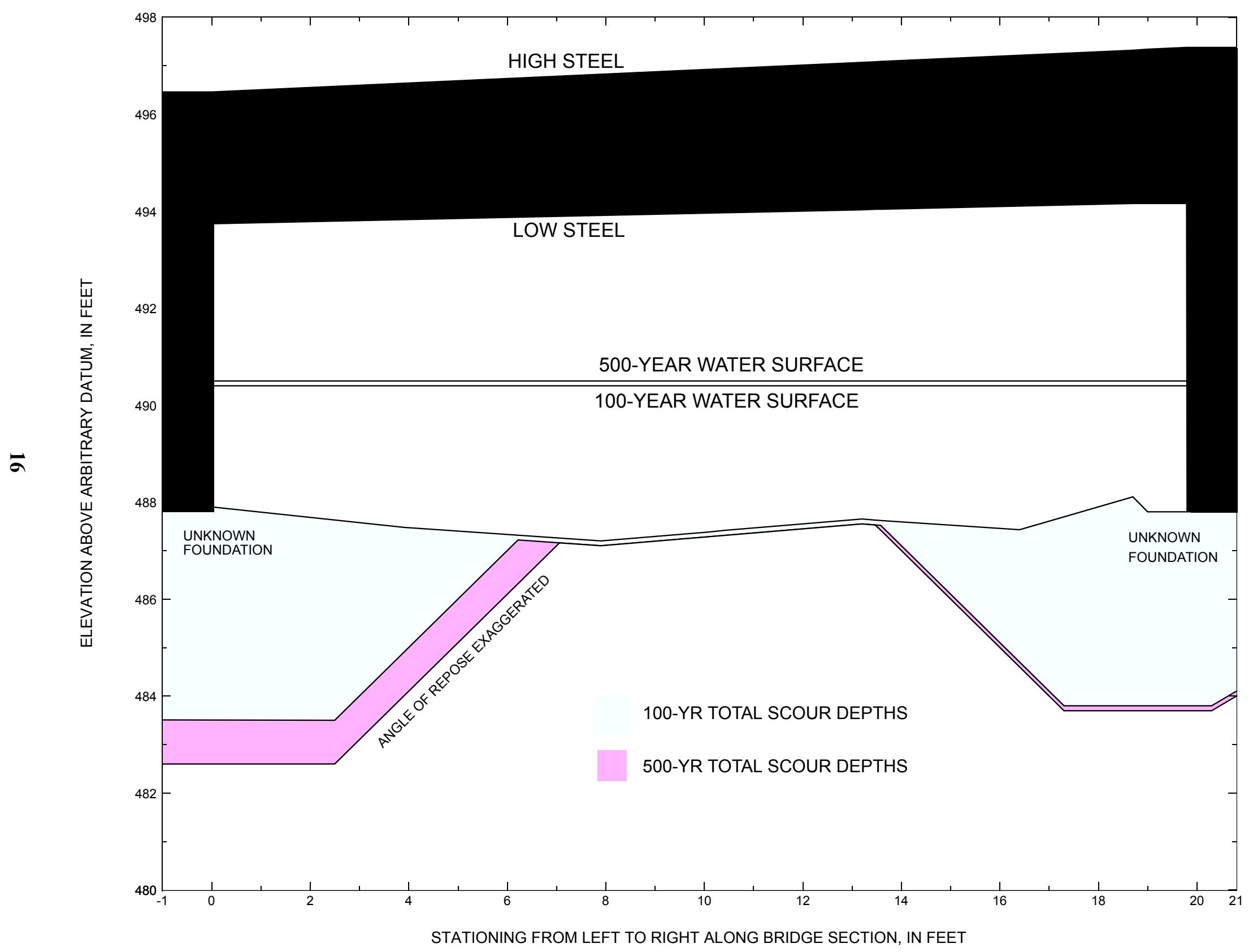

Figure 8. Scour elevations for the 100-yr and 500-yr discharges at structure MNTGTH00020004 on town highway 2, crossing Wade Brook, Montgomery, Vermont. 
Table 1. Remaining footing/pile depth at abutments for the 100-year discharge at structure MNTGTH00020004 on Town Highway 2, crossing Wade Brook, Montgomery, Vermont.

[VTAOT, Vermont Agency of Transportation; --,no data]

\begin{tabular}{|c|c|c|c|c|c|c|c|c|c|c|c|}
\hline Description & Station $^{1}$ & $\begin{array}{l}\text { VTAOT } \\
\text { minimum } \\
\text { low-chord } \\
\text { elevation } \\
\text { (feet) }\end{array}$ & $\begin{array}{l}\text { Surveyed } \\
\text { minimum } \\
\text { low-chord } \\
\text { elevation } \\
\text { (feet) }\end{array}$ & $\begin{array}{l}\text { Bottom of } \\
\text { footing } \\
\text { elevation } \\
\text { (feet) }\end{array}$ & $\begin{array}{l}\text { Channel } \\
\text { elevation at } \\
\text { abutment/ } \\
\text { pier }^{2} \\
\text { (feet) }\end{array}$ & $\begin{array}{l}\text { Contraction } \\
\text { scour depth } \\
\text { (feet) }\end{array}$ & $\begin{array}{l}\text { Abutment } \\
\text { scour } \\
\text { depth } \\
\text { (feet) }\end{array}$ & $\begin{array}{l}\text { Pier } \\
\text { scour } \\
\text { depth } \\
\text { (feet) }\end{array}$ & $\begin{array}{l}\text { Depth of } \\
\text { total scour } \\
\text { (feet) }\end{array}$ & $\begin{array}{c}\text { Elevation of } \\
\text { scour }^{2} \\
\text { (feet) }\end{array}$ & $\begin{array}{c}\text { Remaining } \\
\text { footing/pile } \\
\text { depth } \\
\text { (feet) }\end{array}$ \\
\hline \multicolumn{12}{|c|}{100 -yr. discharge is 460 cubic-feet per second } \\
\hline Left abutment & 0.0 & -- & 493.5 & -- & 487.9 & 0.1 & 4.3 & -- & 4.4 & 483.5 & -- \\
\hline Right abutment & 19.8 & -- & 494.4 & -- & 487.8 & 0.1 & 3.9 & -- & 4.0 & 483.8 & -- \\
\hline
\end{tabular}

1. Measured along the face of the most constricting side of the bridge.

2. Arbitrary datum for this study.

Table 2. Remaining footing/pile depth at abutments for the 500-year discharge at structure MNTGTH00020004 on Town Highway 2, crossing Wade Brook, Montgomery, Vermont.

[VTAOT, Vermont Agency of Transportation; --, no data]

\begin{tabular}{|c|c|c|c|c|c|c|c|c|c|c|c|}
\hline Description & Station $^{1}$ & $\begin{array}{l}\text { VTAOT } \\
\text { minimum } \\
\text { low-chord } \\
\text { elevation } \\
\text { (feet) }\end{array}$ & $\begin{array}{l}\text { Surveyed } \\
\text { minimum } \\
\text { low-chord } \\
\text { elevation } \\
\text { (feet) }\end{array}$ & $\begin{array}{l}\text { Bottom of } \\
\text { footing } \\
\text { elevation } \\
\text { (feet) }\end{array}$ & $\begin{array}{c}\text { Channel } \\
\text { elevation at } \\
\text { abutment/ } \\
\text { pier }^{2} \\
\text { (feet) }\end{array}$ & $\begin{array}{l}\text { Contraction } \\
\text { scour depth } \\
\text { (feet) }\end{array}$ & $\begin{array}{l}\text { Abutment } \\
\text { scour } \\
\text { depth } \\
\text { (feet) }\end{array}$ & $\begin{array}{l}\text { Pier } \\
\text { scour } \\
\text { depth } \\
\text { (feet) }\end{array}$ & $\begin{array}{l}\text { Depth of } \\
\text { total scour } \\
\text { (feet) }\end{array}$ & $\begin{array}{c}\text { Elevation of } \\
\text { scour }^{2} \\
\text { (feet) }\end{array}$ & $\begin{array}{c}\text { Remaining } \\
\text { footing/pile } \\
\text { depth } \\
\text { (feet) }\end{array}$ \\
\hline \multicolumn{12}{|c|}{500 -yr. discharge is 490 cubic-feet per second } \\
\hline Left abutment & 0.0 & -- & 493.5 & -- & 487.9 & 0.1 & 5.2 & -- & 5.3 & 482.6 & -- \\
\hline Right abutment & 19.8 & -- & 494.4 & -- & 487.8 & 0.1 & 4.0 & -- & 4.1 & 483.7 & -- \\
\hline
\end{tabular}

1. Measured along the face of the most constricting side of the bridge.

2. Arbitrary datum for this study. 


\section{SELECTED REFERENCES}

Arcement, G.J., Jr., and Schneider, V.R., 1989, Guide for selecting Manning's roughness coefficients for natural channels and flood plains: U.S. Geological Survey Water-Supply Paper 2339, 38 p.

Barnes, H.H., Jr., 1967, Roughness characteristics of natural channels: U.S. Geological Survey Water-Supply Paper 1849, 213 p.

Brown, S.A. and Clyde, E.S., 1989, Design of riprap revetment: Federal Highway Administration Hydraulic Engineering Circular No. 11, Publication FHWA-IP-89-016, 156 p.

Federal Highway Administration, 1983, Runoff estimates for small watersheds and development of sound design: Federal Highway Administration Report FHWA-RD-77-158

Froehlich, D.C., 1989, Local scour at bridge abutments in Ports, M.A., ed., Hydraulic Engineering--Proceedings of the 1989 National Conference on Hydraulic Engineering: New York, American Society of Civil Engineers, p. 13-18.

Hayes, D.C.,1993, Site selection and collection of bridge-scour data in Delaware, Maryland, and Virginia: U.S. Geological Survey Water-Resources Investigation Report 93-4017, 23 p.

Johnson, C.G. and Tasker, G.D.,1974, Progress report on flood magnitude and frequency of Vermont streams: U.S. Geological Survey Open-File Report 74-130, 37 p.

Lagasse, P.F., Schall, J.D., Johnson, F., Richardson, E.V., Chang, F., 1995, Stream Stability at Highway Structures: Federal Highway Administration Hydraulic Engineering Circular No. 20, Publication FHWA-IP-90-014, 144 p.

Laursen, E.M., 1960, Scour at bridge crossings: Journal of the Hydraulics Division, American Society of Civil Engineers, v. 86, no. HY2, p. 39-53.

Potter, W. D., 1957a, Peak rates of runoff in the Adirondack, White Mountains, and Maine woods area, Bureau of Public Roads

Potter, W. D., 1957b, Peak rates of runoff in the New England Hill and Lowland area, Bureau of Public Roads

Richardson, E.V. and Davis, S.R., 1995, Evaluating scour at bridges: Federal Highway Administration Hydraulic Engineering Circular No. 18, Publication FHWA-IP-90-017, 204 p.

Richardson, E.V., Simons, D.B., and Julien, P.Y., 1990, Highways in the river environment: Federal Highway Administration Publication FHWA-HI-90-016.

Ritter, D.F., 1984, Process Geomorphology: W.C. Brown Co., Debuque, Iowa, 603 p.

Shearman, J.O., 1990, User's manual for WSPRO--a computer model for water surface profile computations: Federal Highway Administration Publication FHWA-IP-89-027, 187 p.

Shearman, J.O., Kirby, W.H., Schneider, V.R., and Flippo, H.N., 1986, Bridge waterways analysis model; research report: Federal Highway Administration Publication FHWA-RD-86-108, 112 p.

Talbot, A.N., 1887, The determination of water-way for bridges and culverts.

U.S. Department of Transportation, 1993, Stream stability and scour at highway bridges, Participant Workbook: Federal Highway Administration Publication FHWA HI-91-011.

U.S. Geological Survey, 1986, Hazens Notch, Vermont 7.5 Minute Series quadrangle map: U.S. Geological Survey Topographic Maps; aerial photography, 1980, contour interval, 6 meters; Scale 1:24,000. 


\section{APPENDIX A: \\ WSPRO INPUT FILE}




\section{WSPRO INPUT FILE}

GR

GR

GR

$\mathrm{XT}$

GR

GR

GR

GR

\section{*}

AS

GT

$\mathrm{N}$

HP 1 BRIDG

HP 2 BRIDG

HP 1 APPRO

HP 2 APPRO

*

HP 1 BRIDG

HP 2 BRIDG
U.S. Geological Survey WSPRO Input File mntg004.wsp Hydraulic analysis for structure MNTGTH00020004 Date: 08-MAR-96

Town Highway 2 (VT 58) Bridge Crossing Wade Brook, Montgomery, VT EMB $\begin{array}{rr}460.0 & 490.0 \\ 0.0454 & 0.0454\end{array}$

$\begin{array}{lllllllllllllllllllll}6 & 29 & 30 & 552 & 553 & 551 & 5 & 16 & 17 & 13 & 3 & * & 15 & 14 & 23 & 21 & 11 & 12 & 4 & 7 & 3\end{array}$ EXITX $\quad-19 \quad 0$.

$\begin{array}{rrrrrr}-100.8,506.89 & -84.9,493.40 & -51.9,494.49 & -22.5,493.76 \\ -13.0,490.42 & -9.5,487.89 & -6.4,487.61 & 0.0,487.15 \\ 7.2,486.96 & 10.1,487.01 & 15.8,487.31 & 20.8,488.52 \\ 24.1,491.40 & 43.6,493.78 & 76.6,509.45 & \end{array}$

$0.035 \quad 0.065$

$-22.5$

FULLV 0 * * * 0.0454

SRD LSEL XSSKEW

$\begin{array}{llll}B R I D G & 0 & 493.96 & 25.0\end{array}$

$0.0,493.48 \quad 0.1,487.89$

$0.2,488.14$

$3.9,487.48$

$7.9,487.20 \quad 13.2,487.65$

$16.4,487.43$

$18.7,488.11$

$19.0,487.82$

$19.8,494.45$

$0.0,493.48$

BRTYPE BRWDTH WWANGL WWWID

$134.8 * * 48 \quad 5.0$

0.055

$\begin{array}{rrrc} & \text { SRD } & \text { EMBWID } & \text { IPAVE } \\ \text { RDWAY } & 15 & 26.0 & 2\end{array}$

$-117.5,505.00-102.8,493.40$

$-5.9,500.75 \quad-3.4,500.78$

$-70.0,494.49$

$-6.1,496.43$

$0.0,500.61$

$14.4,501.49$

$16.9,501.53$

$18.2,501.33$

$18.3,497.31$

$58.4,500.22$

$118.5,506.69$

APTEM 58

$-96.8,506.17$

$-71.0,499.73$

$-26.0,499.83$

$-19.8,493.73$

$-3.7,493.43$

$0.0,491.42$

$3.4,490.65$

$6.1,490.23$

$8.9,490.52$

$12.6,490.53$

$15.0,491.16$

$19.2,493.10$
$108.0,502.29$

$129.8,513.35$
MB 


\section{APPENDIX B: \\ WSPRO OUTPUT FILE}


WSPRO OUTPUT FILE

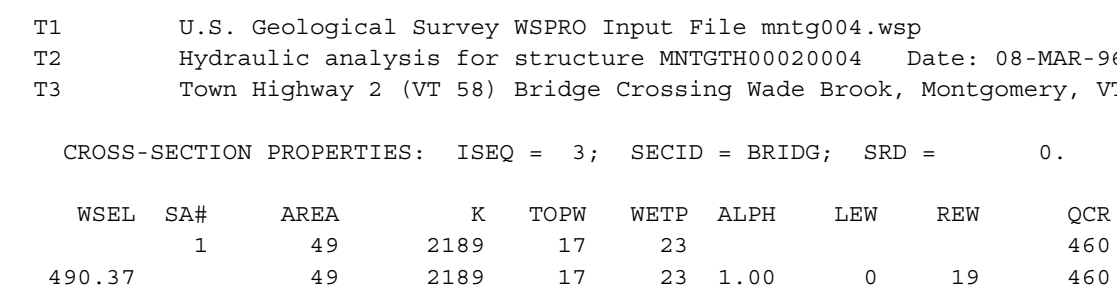

VELOCITY DISTRIBUTION : ISEQ $=3 ; \quad \operatorname{SECID}=$ BRIDG $; \quad$ SRD $=0$.

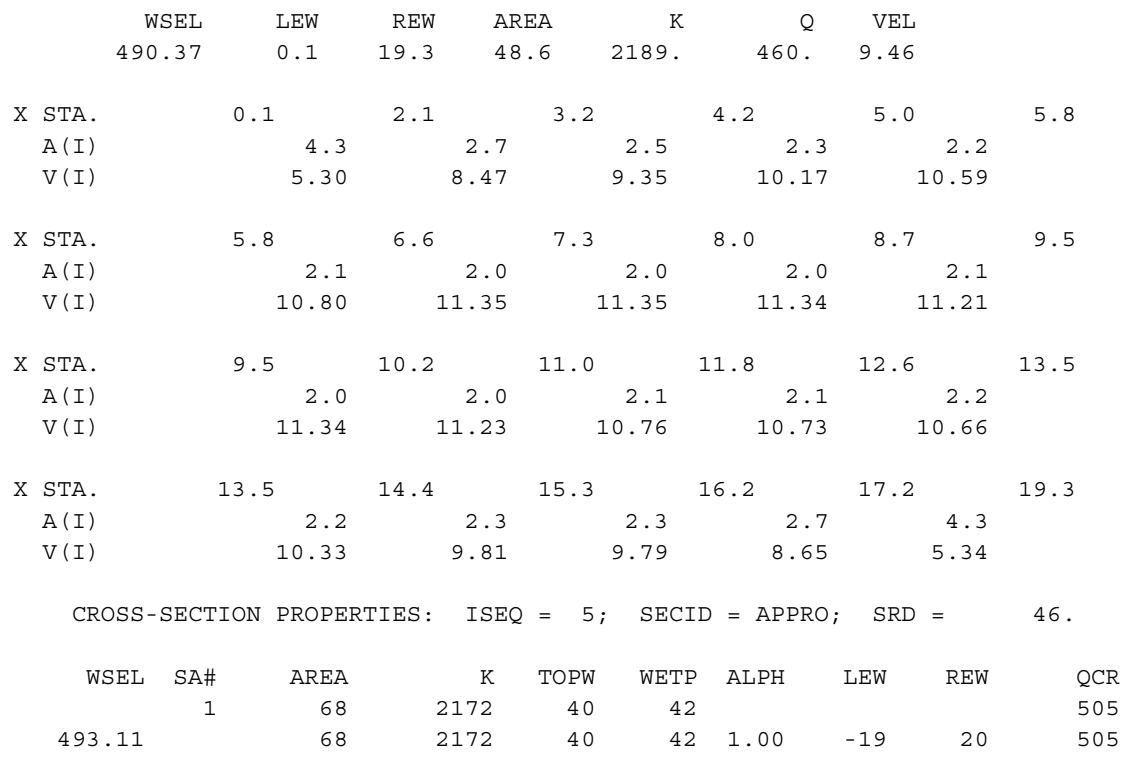

VELOCITY DISTRIBUTION : ISEQ $=5 ;$ SECID $=$ APPRO; $\quad$ SRD $=46$.

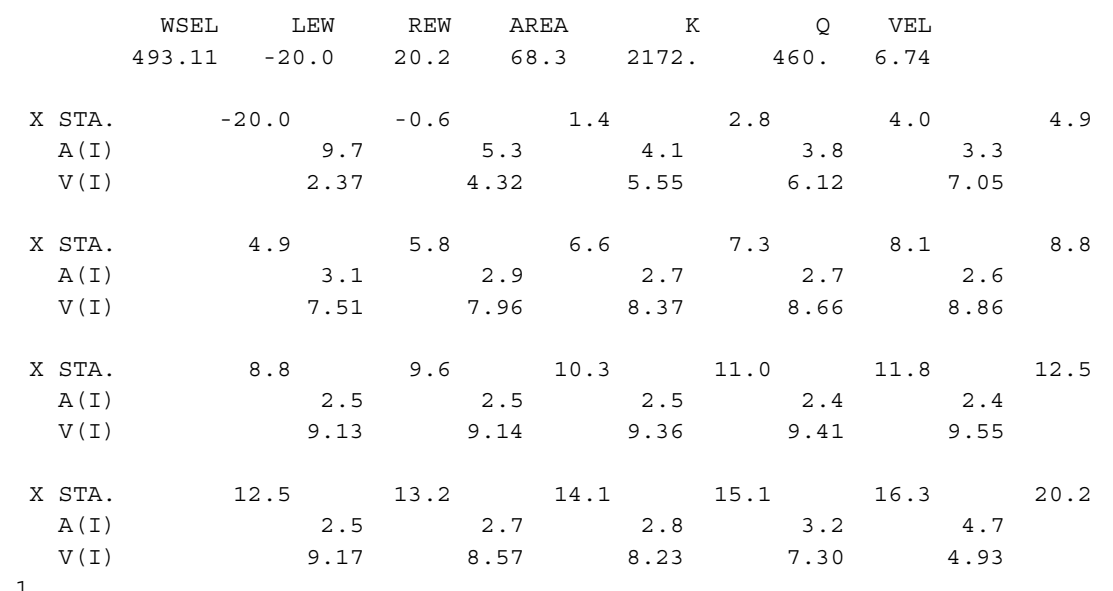


WSPRO OUTPUT FILE (continued)

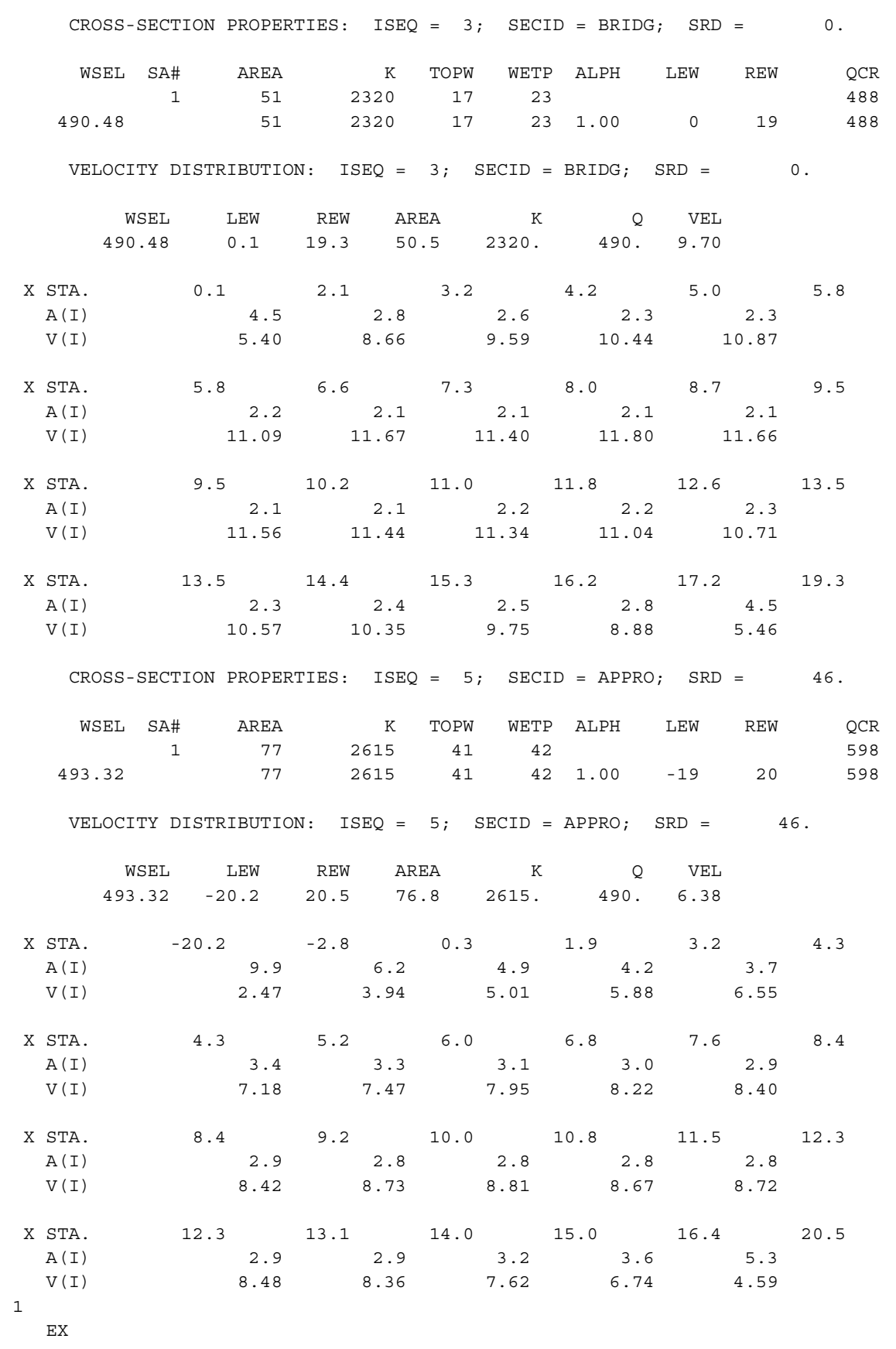


WSPRO OUTPUT FILE (continued)

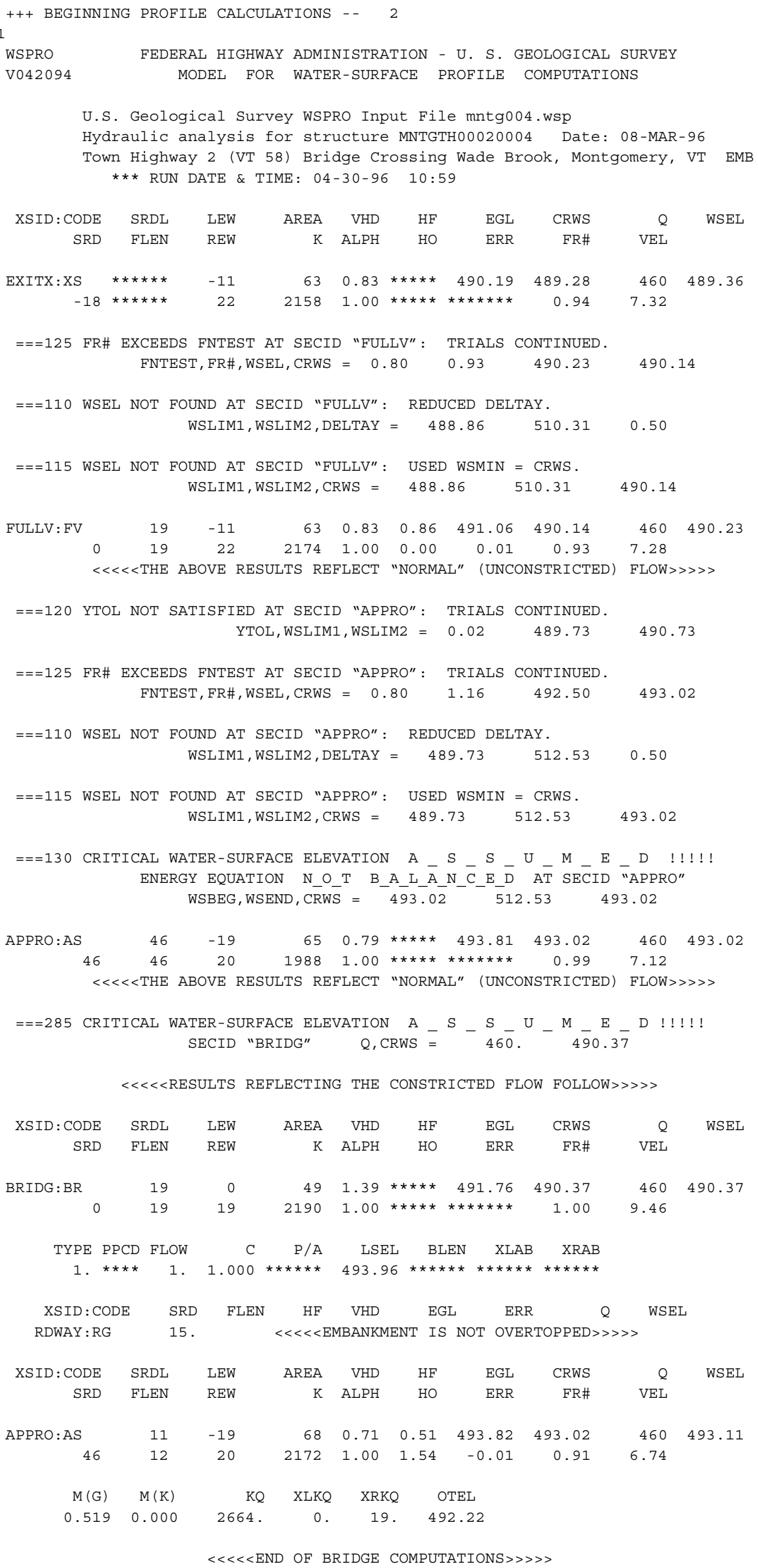


WSPRO OUTPUT FILE (continued)

\begin{tabular}{|c|c|c|c|c|c|c|c|c|}
\hline $\begin{array}{l}\text { FIRST USER D } \\
\text { XSID: CODE }\end{array}$ & $\begin{array}{r}\text { INED } \\
\text { SRD }\end{array}$ & $\begin{array}{l}\text { BLE. } \\
\text { LEW }\end{array}$ & REW & $Q$ & $\mathrm{~K}$ & AREA & VEL & WSEL \\
\hline EXITX:XS & -19. & -12 & 22 . & 460 . & 2158 . & 63. & 7.32 & 489.36 \\
\hline FULLV : FV & 0 . & -12 & 22 . & 460. & 2174 . & 63. & 7.28 & 490.23 \\
\hline BRIDG : BR & 0 . & 0 . & 19. & 460. & 2190. & 49 . & 9.46 & 490.37 \\
\hline RDWAY : RG & \multicolumn{3}{|c|}{ 15. $* * * * * * * * * * \star * * *$} & \multicolumn{3}{|c|}{$0 . * * * * * * * * * * * * * * * * * *$} & \multicolumn{2}{|c|}{$2.00 * \star * \star * \star * *$} \\
\hline APPRO: AS & 46 . & -20 & 20. & 460 . & 2172 . & 68 & 6.74 & 493.11 \\
\hline XSID : CODE & XLKQ & $\mathrm{XRKQ}$ & & & & & & \\
\hline APPRO : AS & 0 . & 19. & 2664 & & & & & \\
\hline
\end{tabular}

SECOND USER DEFINED TABLE.

\begin{tabular}{|c|c|c|c|c|c|c|c|c|c|c|c|}
\hline XSID : CODE & \multicolumn{2}{|c|}{ CRWS } & FR\# & \multicolumn{2}{|c|}{ YMIN } & YMAX & \multicolumn{2}{|r|}{$\mathrm{HO}$} & \multicolumn{2}{|r|}{ EGL } & WSE \\
\hline EXITX:XS & \multicolumn{2}{|c|}{489.28} & 0.94 & & $509.45 *$ & 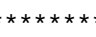 & $\star \star \star \star \star$ & 0.83 & 490.19 & 489.3 \\
\hline FULLV : FV & \multicolumn{2}{|c|}{490.14} & 0.93 & \multicolumn{2}{|c|}{$\begin{array}{l}486.96 \\
487.82\end{array}$} & $\begin{array}{l}509.45^{\star} \\
510.31\end{array}$ & 0.86 & 0.00 & 0.83 & 491.06 & 490. \\
\hline BRIDG : BR & \multicolumn{2}{|c|}{490.37} & 1.00 & \multicolumn{2}{|c|}{$\begin{array}{l}487.82 \\
487.20\end{array}$} & 494.45 & 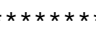 & $\star \star \star \star \star$ & 1.39 & 491.76 & 490. \\
\hline RDWAY : RG & \multirow{2}{*}{\multicolumn{2}{|c|}{$\begin{array}{c}* * * * * * * * * * * \\
493.02\end{array}$}} & \multirow{2}{*}{$\begin{array}{r}* \star * * * \\
0.91\end{array}$} & \multicolumn{2}{|c|}{493.40} & \multicolumn{6}{|c|}{ 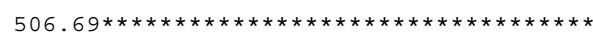 } \\
\hline APPRO: AS & & & & \multicolumn{2}{|c|}{489.41} & 512.53 & 0.51 & 1.54 & 0.71 & 493.82 & 493.1 \\
\hline D : CODE & SRDL & LEW & & REA & VHD & $\mathrm{HF}$ & EGI & & RWW & Q & WSEL \\
\hline SRD & FLEN & REW & & K & $\mathrm{ALPH}$ & $\mathrm{HO}$ & ERI & & FR\# & VEL & \\
\hline TX:XS & $* * *$ & -11 & & 65 & 0.87 & $\star \star \star \star * \star$ & 490.3 & 489 & 9.35 & 490 & 489.44 \\
\hline-18 & $\star * \star *$ & 22 & & 2299 & 1.00 & $\star \star \star \star \star \star *$ & $\star \star \star \star \star \star * \star *$ & & .94 & 7.48 & \\
\hline
\end{tabular}

$===125$ FR\# EXCEEDS FNTEST AT SECID "FULLV": TRIALS CONTINUED.

FNTEST, FR\#, WSEL, CRWS $=\begin{array}{lllll}0.80 & 0.94 & 490.31 & 490.22\end{array}$

$==110$ WSEL NOT FOUND AT SECID "FULLV": REDUCED DELTAY.

$$
\text { WSLIM1, WSLIM2, DELTAY }=488.94 \quad 510.31 \quad 0.50
$$

$==115$ WSEL NOT FOUND AT SECID "FULLV": USED WSMIN = CRWS. WSLIM1, WSLIM2, CRWS $=488.94 \quad 510.31 \quad 490.22$

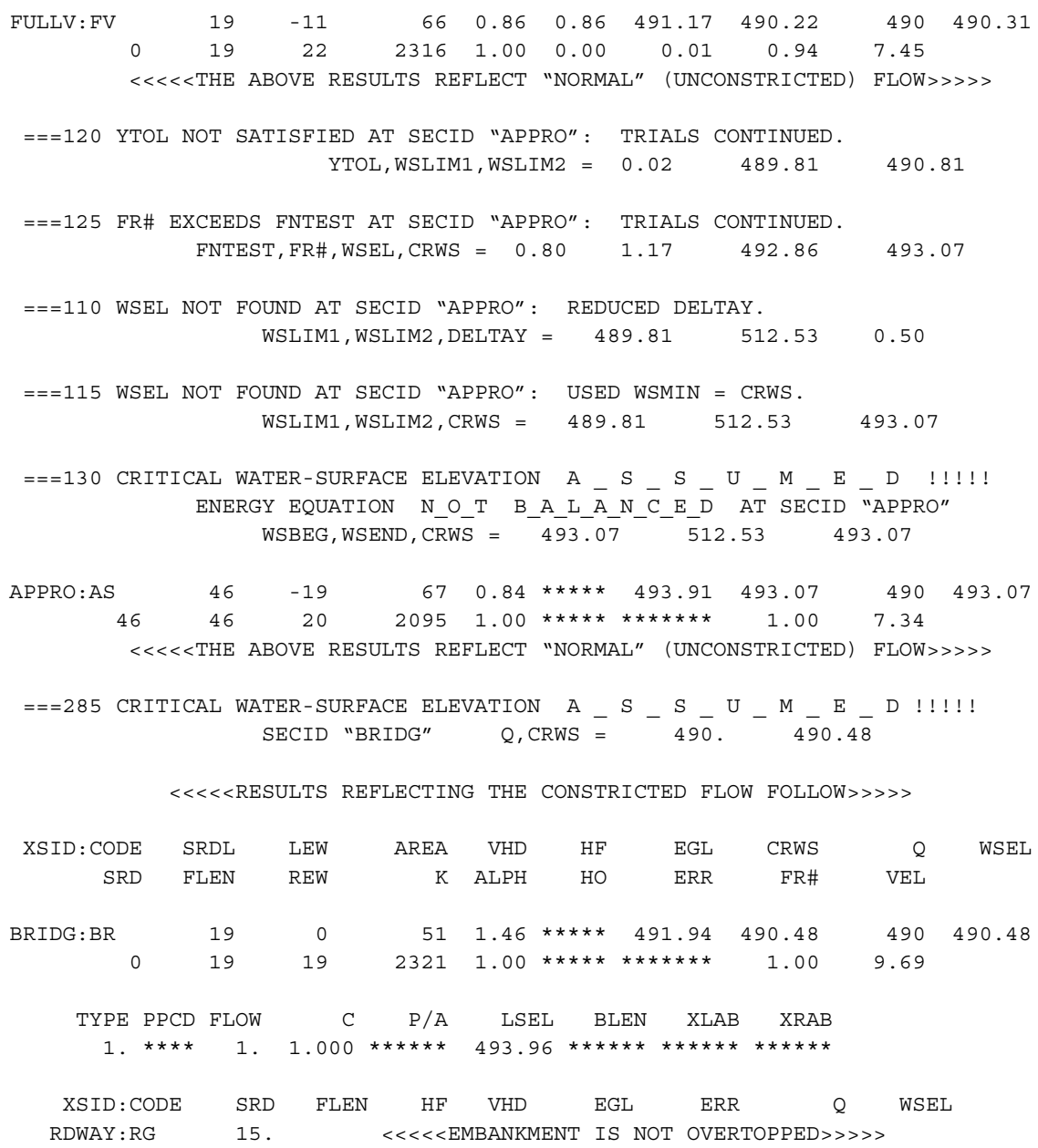


WSPRO OUTPUT FILE (continued)

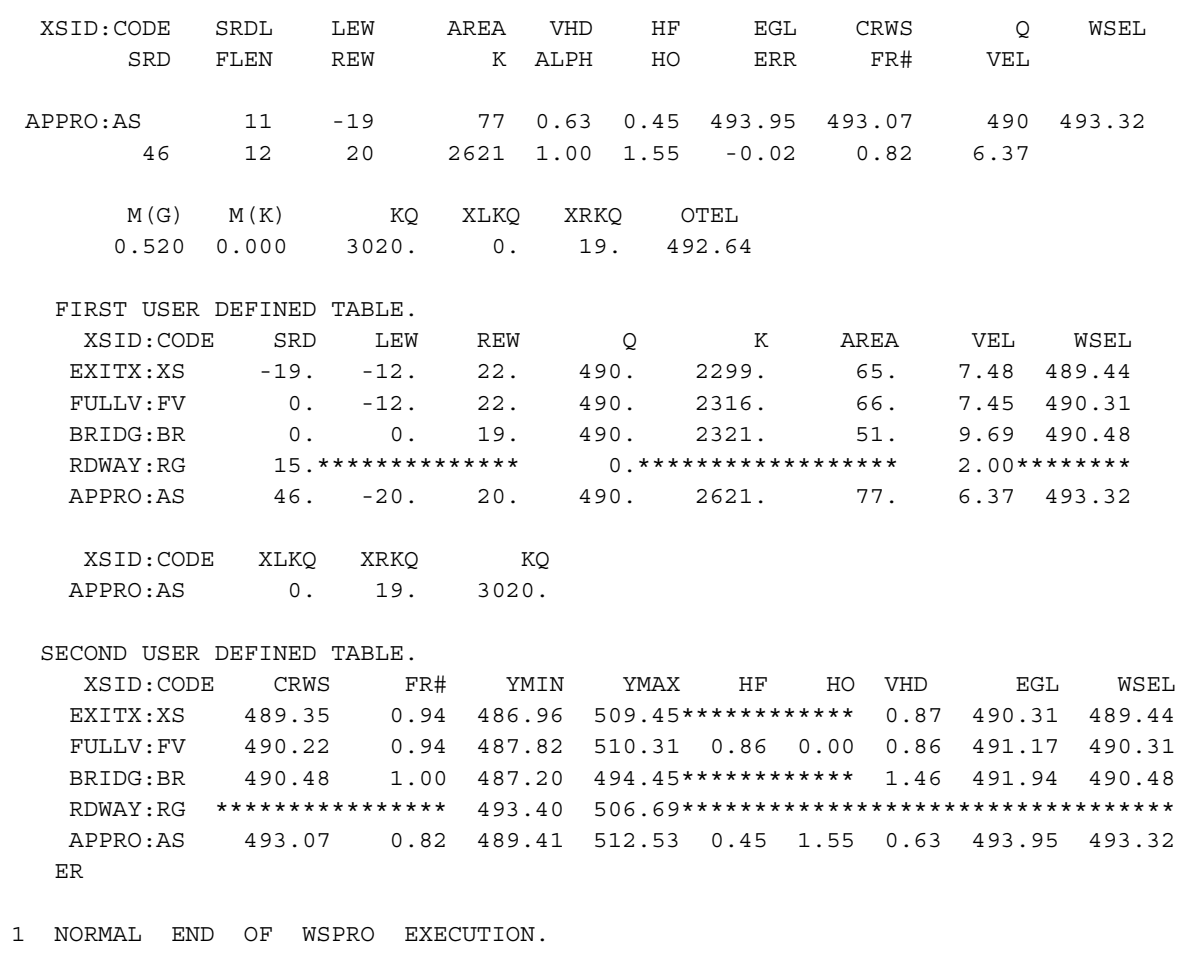




\section{APPENDIX C:}

\section{BED-MATERIAL PARTICAL-SIZE DISTRIBUTION}




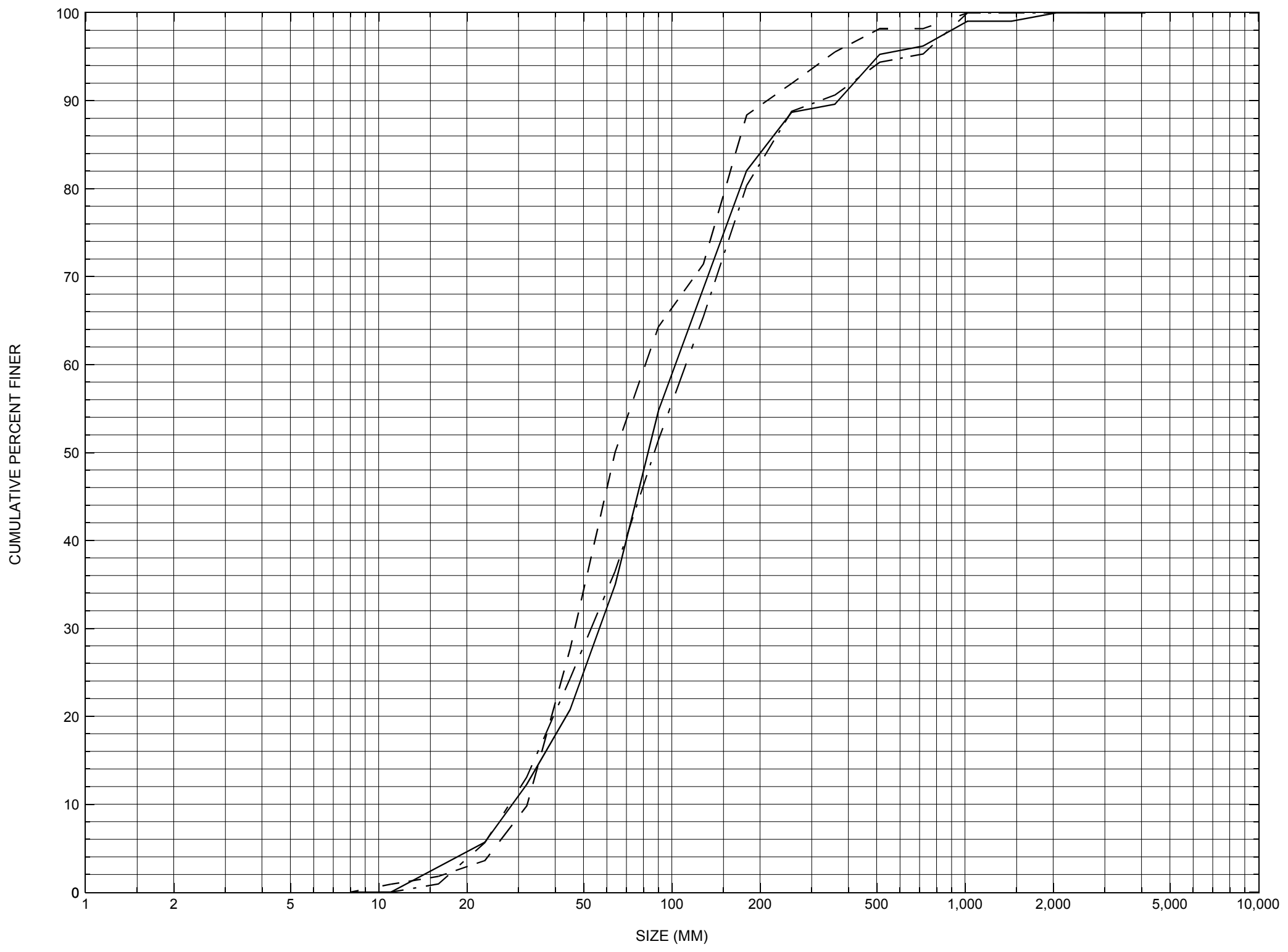

Appendix C. Bed material particle-size distributions for three pebble count transects at the approach cross-section for structure MNTGTH00020004, in Montgomery, Vermont. 


\section{APPENDIX D: \\ HISTORICAL DATA FORM}




\section{Structure Number MTNGTH00020004}

\section{General Location Descriptive}

Data collected by (First Initial, Full last name) $\mathbf{E}$. BOEHMLER

Date $(M M / D D / Y Y) \_\mathbf{0 8} / \underline{\mathbf{0 3}} / \underline{\mathbf{9 4}}$

Highway District Number (I - 2; nn) $\mathbf{0 8}$

Town (FIPS place code; I - 4; nnnnn) $\mathbf{4 5 8 5 0}$

Waterway $(I$ - 6) WADE BROOK

Route Number $\mathbf{\text { TH002 }}$

Topographic Map Hazens.Notch

Latitude (I - 16; nnnn.n) $\mathbf{4 4 5 0 9}$
County (FIPS county code; I - 3; nnn)

Mile marker (I - 11; nnn.nnn) $\mathbf{0 0 3 9 6 0}$

Road Name (I - 7): -

Vicinity (I - 9) 3.0 MI E JCT. VT.118

Hydrologic Unit Code: $\mathbf{0 2 0 1 0 0 0 7}$

Longitude (i - 17; nnnnn.n) $\mathbf{7 2 3 2 8}$

\section{Select Federal Inventory Codes}

FHWA Structure Number $(I$ - 8) $\mathbf{2 0 0 3 0 8 0 0 0 4 0 6 1 0}$

Maintenance responsibility $(I-21 ; n n) \quad \mathbf{0 3}$

Year built (I - 27; YYYY) 1928

Average daily traffic, ADT (I - 29; nnnnnn) 000200

Year of ADT (I - 30; YY) $\mathbf{9 1}$

Opening skew to Roadway $(I-34 ; n n) \quad 30$

Operational status $(I-41 ; X) \quad \mathbf{A}$

Structure type (I - 43; nnn) 101

Approach span structure type (I - 44; nnn) $\mathbf{0 0 0}$

Number of spans (I - 45; nnn) $\mathbf{0 0 1}$

Number of approach spans (I - 46; nnnn) $\mathbf{0 0 0 0}$

Comments:

Structural inspection report of $9 / 26 / 92$ indicates a full depth crack has developed in the left abutment from top to bottom near the center and has been undermined. However, the same inspection indicates channel scour is minor. Embankment erosion was noted on the right embankment upstream and both downstream. The channel makes a moderate bend into and through bridge. The report indicates no riprap protection present. debris had collected on the banks.
Maximum span length (I - 48; nnnn) $\underline{\mathbf{0 0 2 0}}$

Structure length (I - 49; nnnnnn) $\underline{\mathbf{0 0 0 0 2 3}}$

Deck Width (I - 52; nn.n) $\mathbf{2 6 0}$

Channel \& Protection $(I-61 ; n) \underline{6}$

Waterway adequacy $(I-71 ; n) \underline{5}$

Underwater Inspection Frequency $(I-92 B ; X Y Y) \_\mathbf{N}$

Year Reconstructed (I - 106) $\mathbf{0 0 0 0}$

Clear span (nnn.n ft) _

Vertical clearance from streambed (nnn.n ft) $\underline{\mathbf{0 0 6 . 0}}$

Waterway of full opening $\left(n n n . n \mathrm{ft}^{2}\right)$ 


\section{Bridge Hydrologic Data}

Is there hydrologic data available? $\underline{\mathbf{N}}$ if No, type ctrl-n $h \quad$ VTAOT Drainage area $\left(m i^{2}\right)$ : -

Terrain character:

Stream character \& type: -

Streambed material: Boulder

Discharge Data (cfs): $\quad Q_{2.33}-$

$$
\mathrm{Q}_{50}-
$$

Record flood date (MM / DD / YY): -

Estimated Discharge (cfs): I

$\mathrm{Q}_{10}-$

$\mathrm{Q}_{25}$

Water surface elevation $(f t):-$

Ice conditions (Heavy, Moderate, Light) : -

Velocity at $\mathrm{Q}$ $(\mathrm{ft} / \mathrm{s}):$

The stage increases to maximum highwater elevation (Rapidly, Not rapidly):

The stream response is (Flashy, Not flashy):

Describe any significant site conditions upstream or downstream that may influence the stream's stage: -

Watershed storage area (in percent): - _ \%

The watershed storage area is: - _ (1-mainly at the headwaters; 2- uniformly distributed; 3-immediatly upstream oi the site)

Water Surface Elevation Estimates for Existing Structure:

\begin{tabular}{|l|l|l|l|l|l|}
\hline Peak discharge frequency & $Q_{2.33}$ & $Q_{10}$ & $Q_{25}$ & $Q_{50}$ & $Q_{100}$ \\
Water surface elevation (ft)) & - & - & - & - & - \\
Velocity (ft/sec) & - & - & - & - & - \\
\hline
\end{tabular}

Long term stream bed changes: -

Is the roadway overtopped below the $\mathrm{Q}_{100}$ ? (Yes, No, Unknown): $\mathbf{U}$ Frequency: Relief Elevation (ft): Discharge over roadway at $Q_{100}\left(f^{3} / \mathrm{sec}\right)$ :

Are there other structures nearby? (Yes, No, Unknown): $\mathbf{U}$ Upstream distance (miles): Town: If No or Unknown, type ctrl-n os Highway No. : Structure No. : Year Built:

Clear span (ft): Clear Height (ft): Full Waterway $\left(f^{2}\right)$ : 
Downstream distance (miles): Town: Year Built:

Highway No. : Structure No. : Structure Type:

Clear span (ft): Clear Height $(f t)$ : Full Waterway $\left(f t^{2}\right)$ :

Comments:

\section{USGS Watershed Data}

Watershed Hydrographic Data

Drainage area $(D A) \underline{1.68}$

Watershed storage (ST)

Bridge site elevation

Main channel length

1326

1.93

$10 \%$ channel length elevation $\mathrm{mi}^{2}$ 0 $\%$

Lake and pond area

$\mathbf{0}$ $\mathrm{mi}^{2}$

Headwater elevation 3196 $\mathrm{ft}$ mi

Main channel slope (S)

(S) 852.16 $\mathrm{ft} \quad 85 \%$ channel length elevation 2657 $\mathrm{ft}$

Watershed Precipitation Data

Average site precipitation in

Average headwater precipitation in

Maximum 2yr-24hr precipitation event $(124,2)$ in

Average seasonal snowfall (Sn) $\mathrm{ft}$ 


\section{Bridge Plan Data}

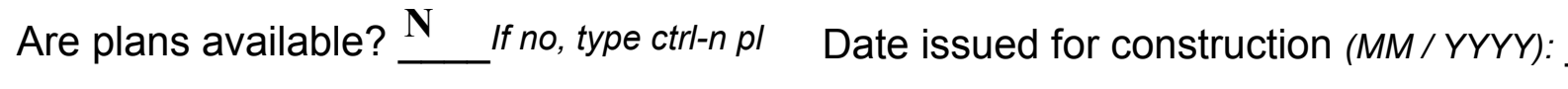

Project Number

Minimum channel bed elevation:

Low superstructure elevation: USLAB DSLAB USRAB DSRAB Benchmark location description:

-

Reference Point (MSL, Arbitrary, Other):

Datum (NAD27, NAD83, Other):

Foundation Type: 4

If 1 : Footing Thickness

If 2: Pile Type:

If 3: Footing bottom elevation:

Is boring information available? $\mathbf{N}$

Foundation Material Type: $\mathbf{3}$

(1-Spreadfooting; 2-Pile; 3- Gravity; 4-Unknown)

Footing bottom elevation: -

Briefly describe material at foundation bottom elevation or around piles:

NO FOUNDATION MATERIAL INFORMATION

Comments:

NO PLANS. 


\section{Cross-sectional Data}

Is cross-sectional data available? $\mathbf{N}$ If no, type ctrl-n xs

Source (FEMA, VTAOT, Other)? -

Comments: NO CROSS SECTION INFORMATION

\begin{tabular}{|l|l|l|l|l|l|l|l|l|l|l|l|}
\hline Station & - & - & - & - & - & - & - & - & - & - & - \\
\hline Feature & - & - & - & - & - & - & - & - & - & - & - \\
\hline $\begin{array}{l}\text { Low cord } \\
\text { elevation }\end{array}$ & - & - & - & - & - & - & - & - & - & - & - \\
\hline $\begin{array}{l}\text { Bed } \\
\text { elevation }\end{array}$ & - & - & - & - & - & - & - & - & - & - & - \\
\hline $\begin{array}{l}\text { Low cord to } \\
\text { bed length }\end{array}$ & - & - & - & - & - & - & - & - & - & - & - \\
\hline Station & - & - & - & - & - & - & - & - & - & - & - \\
\hline Feature & - & - & - & - & - & - & - & - & - & - & - \\
\hline $\begin{array}{l}\text { Low cord } \\
\text { elevation }\end{array}$ & - & - & - & - & - & - & - & - & - & - & - \\
\hline $\begin{array}{l}\text { Bed } \\
\text { elevation }\end{array}$ & - & - & - & - & - & - & - & - & - & - & - \\
\hline $\begin{array}{l}\text { Low cord to } \\
\text { bed length }\end{array}$ & - & - & - & - & - & - & - & - & - & - & - \\
\hline
\end{tabular}

Source (FEMA, VTAOT, Other)?

Comments: NO CROSS SECTION INFORMATION

\begin{tabular}{|l|l|l|l|l|l|l|l|l|l|l|l|}
\hline Station & - & - & - & - & - & - & - & - & - & - & - \\
\hline Feature & - & - & - & - & - & - & - & - & - & - & - \\
\hline $\begin{array}{l}\text { Low cord } \\
\text { elevation }\end{array}$ & - & - & - & - & - & - & - & - & - & - & - \\
\hline $\begin{array}{l}\text { Bed } \\
\text { elevation }\end{array}$ & - & - & - & - & - & - & - & - & - & - & - \\
\hline $\begin{array}{l}\text { Low cord to } \\
\text { bed length }\end{array}$ & - & - & - & - & - & - & - & - & - & - & - \\
\hline Station & - & - & - & - & - & - & - & - & - & - & - \\
\hline Feature & - & - & - & - & - & - & - & - & - & - & - \\
\hline $\begin{array}{l}\text { Low cord } \\
\text { elevation }\end{array}$ & - & - & - & - & - & - & - & - & - & - & - \\
\hline $\begin{array}{l}\text { Bed } \\
\text { elevation }\end{array}$ & - & - & - & - & - & - & - & - & - & - & - \\
\hline $\begin{array}{l}\text { Low cord to } \\
\text { bed length }\end{array}$ & - & - & - & - & - & - & - & - & - & - & - \\
\hline
\end{tabular}




\section{APPENDIX E: \\ LEVEL I DATA FORM}


U. S. Geological Survey

Bridge Field Data Collection and Processing Form

Qa/Qc Check by: MAI Date: 2/7/95

\section{Structure Number MTNGTH00020004}

Computerized by: EMB Date: $\underline{\text { 2/7/95 }}$

Reviewd by: SAO Date: $\underline{\mathbf{5} / \mathbf{2 3} / 96}$

\section{A. General Location Descriptive}

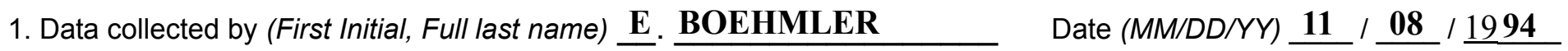

2. Highway District Number 09

County FRANKLIN (011)

Waterway (I - 6) WADE BROOK

Route Number TH02

3. Descriptive comments:

Structure is a concrete slab type bridge with tall concrete guard walls on each side located about 3.0 miles east from the intersection of TH02 with VT118 and about 1.3 miles west of the Hazen Notch on TH02.

\section{B. Bridge Deck Observations}
4. Surface cover... LBUS 6
RBUS 6
LBDS 6
RBDS 6
Overall 6

(2b us, ds,lb,rb: 1- Urban; 2- Suburban; 3- Row crops; 4- Pasture; 5- Shrub- and brushland; 6- Forest; 7- Wetland)
5. Ambient water surface... US 2
UB 2
DS $\underline{2}$
(1- pool; 2- riffle)

6. Bridge structure type 1 (1- single span; 2- multiple span; 3- single arch; 4- multiple arch; 5-cylindrical culvert; 6- box culvert; or 7- other)
7. Bridge length $\underline{\mathbf{2 3 . 0}}$
(feet)
Span length $\mathbf{2 0 . 0}$
(feet)
Bridge width 26.0 (feet)

\section{Road approach to bridge:}
8. LB 1
RB 2
( 0 even, 1- lower, 2- higher)
9. LB_
RB $\underline{2}$
(1-Paved, 2- Not paved)

10. Embankment slope (run / rise in feet / foot)

US left

0.0:1

US right

0.0:1

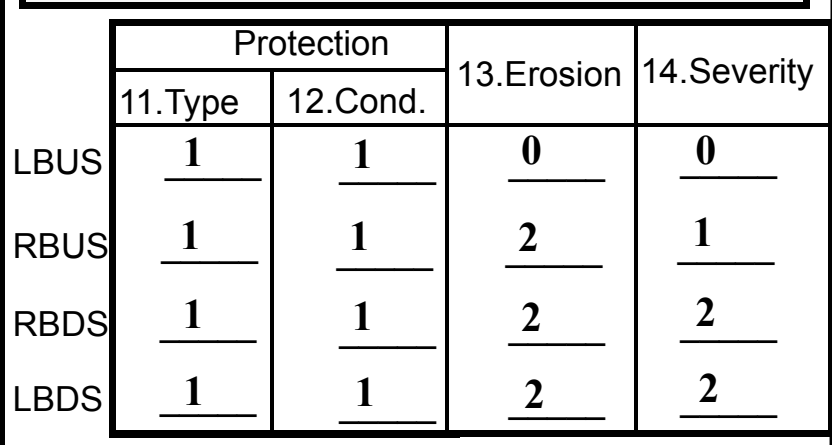

Bank protection types: 0- none; 1- < 12 inches;

2- < 36 inches; 3- < 48 inches;

4- < 60 inches; 5- wall / artificial levee

Bank protection conditions: 1- good; 2- slumped;

3- eroded; 4- failed

Erosion: 0 - none; 1- channel erosion; 2 -

road wash; 3- both; 4- other

Erosion Severity: 0 - none; 1- slight; 2- moderate; 3- severe

\section{Channel approach to bridge (BF):}

15. Angle of approach: $\mathbf{2 0}$

16. Bridge skew: $\mathbf{3 0}$

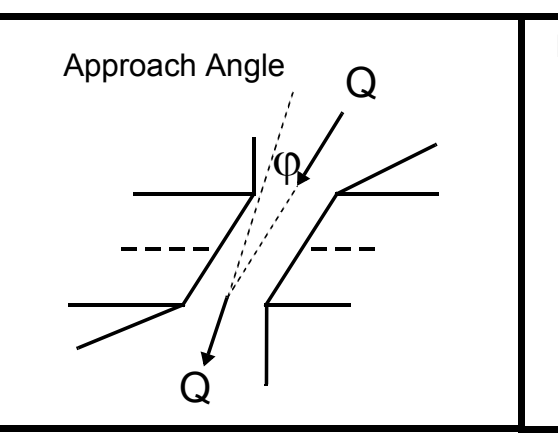

17. Channel impact zone 1 :

Where? LB (LB, RB)

Exist? $\mathbf{Y}(Y$ or $N)$ Bridge Skew Angle

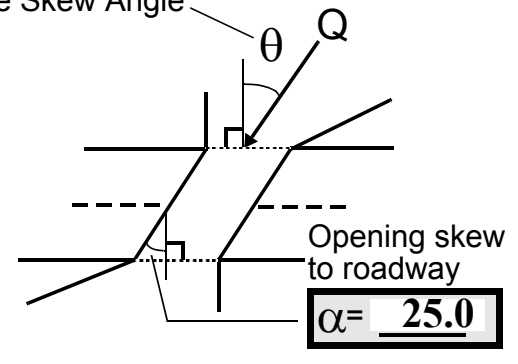

Range? 90 feet US

Severity 2

Channel impact zone 2:

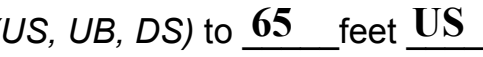

Where? RB (LB, RB)

Exist? $\mathbf{Y}(Y$ or $N)$

Range? 10 feet DS

Severity 2

Impact Severity: 0- none to very slight; 1- Slight; 2- Moderate; 3- Severe 
18. Level II Bridge Type: $\underline{\mathbf{1 A} / \mathbf{4}}$

1a- Vertical abutments with wingwalls

$1 \mathrm{~b}$ - Vertical abutments without wingwalls

2- Vertical abutments and wingwalls, sloping embankment Wingwalls perpendicular to abut. face

3- Spill through abutments

4- Sloping embankment, vertical wingwalls and abutments Wingwall angle less than $90^{\circ}$.

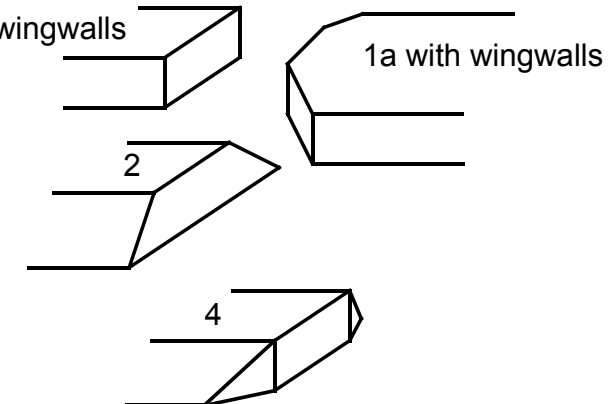

19. Bridge Deck Comments (surface cover variations, measured bridge and span lengths, bridge type variations, approach overflow width, etc.)

The roadway embankments at three of the four corners of the bridge are vertical. Only that of the downstream left bank exists with roughly a 5:1 slope. The surface coverage indicated is actual with little or no deviation. Measurements of the bridge dimensions were the same as those found on the historical form. Roadwash around the end of the downstream left and right wingwalls and at the downstream left road approach embankment are the locations of the most severe erosion. Particularly the downstream left road embankment where gullying has developed in the embankment fill perhaps mostly during periods of roadway overflow. Protection on the upstream left embankment is placed such that it channels the water under the bridge until the level rises above the bridge deck level roughly.

\section{Upstream Channel Assessment}

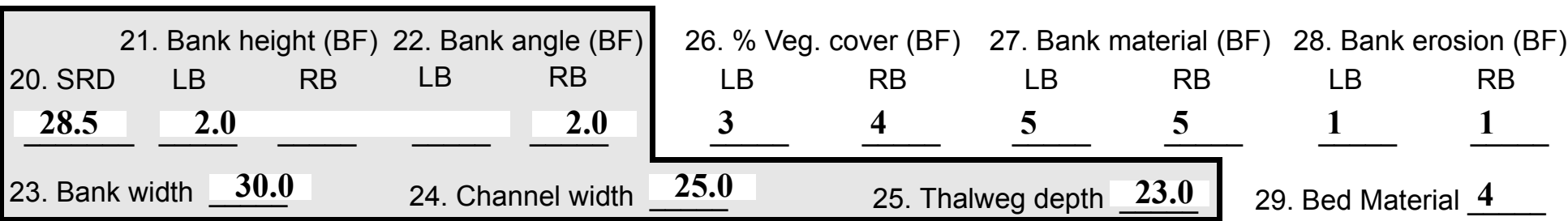

\section{0 .Bank protection type:}

LB 5

RB 0

31. Bank protection condition:

LB 1

RB -

SRD - Section ref. dist. to US face \% Vegetation (Veg) cover: 1- 0 to 25\%; 2- 26 to 50\%; 3- 51 to $75 \%$; 4- 76 to $100 \%$

Bed and bank Material: 0- organics; 1- silt / clay, <1/16mm; 2- sand, 1/16 - 2mm; 3- gravel, 2 - 64mm;

4- cobble, 64 - 256mm; 5- boulder, > 256mm; 6- bedrock; 7- manmade

Bank Erosion: 0- not evident; 1- light fluvial; 2- moderate fluvial; 3- heavy fluvial / mass wasting

Bank protection types: 0- absent; 1- < 12 inches; 2- < 36 inches; 3- < 48 inches; 4- < 60 inches; 5- wall / artificial levee

Bank protection conditions: 1- good; 2- slumped; 3- eroded; 4- failed

32. Comments (bank material variation, minor inflows, protection extent, etc.):

The left bank is protected to 15 feet upstream from the upstream end of the left wingwall. The protection is a dry masonry wall constructed with field stones stacked about 4 diameters high. the channel makes a moderate bend upstream but flows fairly straight through the bridge. The bank material is incohesive as area is mostly boulders with a very thin topsoil layer over them. While non-cohesive, the bank material in part is very large and erosion is not evident upstream except in very localized areas particularly near the impact zone. Although the impact is moderate due to a moderate right bend in the channel, the influence of the impact on the left bank is very slight. 
33.Point/Side bar present? $\mathbf{N}(Y$ or $N$. if $N$ type ctrl-n pb)34. Mid-bar distance: -

35. Mid-bar width: -

36. Point bar extent: feet (US, UB) to feet (US, UB, DS) positioned $\%$ LB to $\% \mathrm{RB}$

37. Material: -

38. Point or side bar comments (Circle Point or Side; Note additional bars, material variation, status, etc.):

NO POINT BARS

39. Is a cut-bank present? $\underline{\mathbf{N}}$ (Y or if $\mathrm{N}$ type ctrl-n cb)

40. Where? - $\quad$ (LB or RB)

41. Mid-bank distance: -

42. Cut bank extent: feet (US, UB) to feet (US, UB, DS)

43. Bank damage: (1- eroded and/or creep; 2- slip failure; 3- block failure)

44. Cut bank comments (eg. additional cut banks, protection condition, etc.):

NO CUT BANKS

45. Is channel scour present? $\mathbf{N}$ ( $Y$ or if $N$ type ctrl-n cs)

47. Scour dimensions: Length Width Depth : 46. Mid-scour distance:

48. Scour comments (eg. additional scour areas, local scouring process, etc.):

NO CHANNEL SCOUR

49. Are there major confluences? $\mathbf{N}$

51. Confluence 1: Distance Confluence 2: Distance 52. Enters on Enters on 54. Confluence comments (eg. confluence name):

NO MAJOR CONFLUENCES
50. How many? -

53. Type(1-perennial; 2- ephemeral)

Type (1-perennial; 2-ephemeral) ( $L B$ or $R B)$

\section{Under Bridge Channel Assessment}

55. Channel restraint (BF)? LB 2

\begin{tabular}{|ccccc}
\hline \multicolumn{2}{|c}{ 56. Height (BF) } & \multicolumn{3}{c}{57 Angle (BF) } \\
LB & RB & LB & RB \\
$\mathbf{1 5 . 0}$ & & & $\mathbf{1 . 0}$ & \\
\hline
\end{tabular}
(1- natural bank; 2- abutment; 3- artificial levee)

58. Bank width (BF) 59. Channel width (Amb) -

61. Material (BF)

LB RB

$\underline{2} \quad \underline{7}$
62. Erosion (BF)

LB RB

7

63. Bed Material -

Bed and bank Material: 0- organics; 1- silt / clay, < 1/16mm; 2- sand, 1/16 - 2mm; 3- gravel, 2 - 64mm; 4- cobble, 64 - 256mm; 5- boulder, > 256mm; 6- bedrock; 7- manmade

Bank Erosion: 0- not evident; 1- light fluvial; 2- moderate fluvial; 3- heavy fluvial / mass wasting

64. Comments (bank material variation, minor inflows, protection extent, etc.):

4

The channel gradient reduces from the upstream reach to the under bridge and downstream reach, but remains enough that the water surface continues riffled through the entire reach. For the most part, the bed material is the same as upstream. However, here the bed material is more compact with fewer voids between the larger stones, more sand and gravel, and a smoother texture. 
65. Debris and Ice Is there debris accumulation?

67. Debris Potential 1 (1- Low; 2- Moderate; 3- High)

69. Is there evidence of ice build-up? $\underline{1}(Y$ or $N)$

70. Debris and Ice Comments:

1

Tree stems, branches, and leaves are scattered about in the channel upstream but not all accumulated in one mass at any one particular location. The steep channel gradient and high velocity flows probably would align debris parallel with the bridge abutments and allow debris to pass through the bridge.

\begin{tabular}{|l|c|c|c|c|c|c|c|c|}
\hline Abutments & $\begin{array}{c}\text { 71. Attack } \\
\angle \text { (BF) }\end{array}$ & $\begin{array}{c}\text { 72. Slope } \angle \\
\text { (Qmax) }\end{array}$ & $\begin{array}{c}\text { 73. Toe } \\
\text { loc. (BF) }\end{array}$ & $\begin{array}{c}\text { 74. Scour } \\
\text { Condition }\end{array}$ & $\begin{array}{c}75 . \text { Scour } \\
\text { depth }\end{array}$ & $\begin{array}{c}\text { 76. Exposure } \\
\text { depth }\end{array}$ & 77. Material & 78. Length \\
\hline LABUT & & $\mathbf{0}$ & $\mathbf{9 0}$ & $\mathbf{0}$ & $\mathbf{2}$ & $\mathbf{0}$ & $\mathbf{1 . 5}$ & $\mathbf{9 0 . 0}$ \\
\hline RABUT & $\mathbf{1}$ & $\mathbf{0}$ & $\mathbf{9 0}$ & & & $\mathbf{0}$ & $\mathbf{3}$ & $\mathbf{1 8 . 0}$ \\
\hline
\end{tabular}

Pushed: $L B$ or RB

Toe Location (Loc.): 0- even, 1- set back, 2- protrudes

Scour cond.: 0- not evident; 1- evident (comment); 2- footing exposed; 3-undermined footing; 4- piling exposed; 5- settled; 6- failed

Materials: 1- Concrete; 2- Stone masonry or drywall; 3- steel or metal; 4- wood

79. Abutment comments (eg. undermined penetration, unusual scour processes, debris, etc.):

0

2.0

1

A two inch wide crack appears at the road center line under the bridge roughly completely through the right abutment footing. The footing has settled from undermining most likely as the footer and right abutment wall are separated slightly by a 0.5 inch crack which runs its length. A large vertical crack has developed in the right abutment wall and is displaced from the footing's crack between two and three feet downstream. The left abutment footing is undermined mainly from concrete deterioration and subsequent erosion rather than by channel erosion. The most significant deterioration and erosion of the concrete left abutment footing is from the upstream end to approximately the roadway center line under the bridge. Both footings appear at

80. Wingwalls:

Exist? Material? Scour Scour Exposure Angle? Length? Condition? depth? depth?

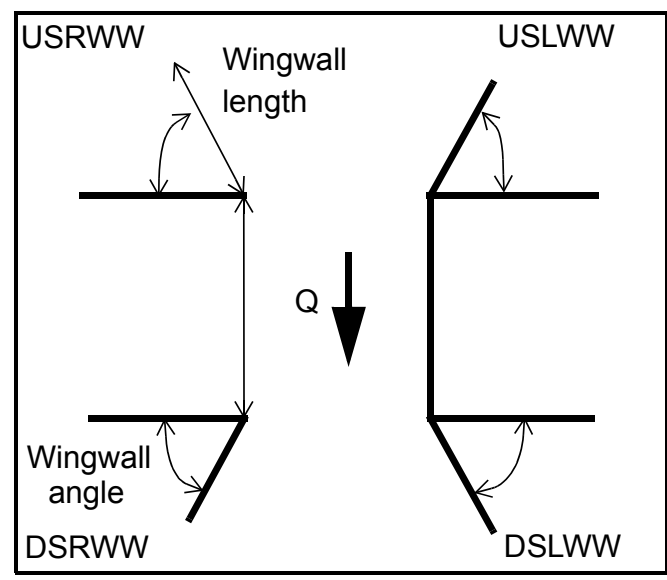

USLWW: most

2

USRWW: thick

DSLWW: tling

DSRWW: right

feet

+ and

of

abut

$\underline{\text { abut }}$

Wingwall materials: 1- Concrete; 2- Stone masonry or drywall; 3- steel or metal; 4- wood

18.0

set-

the

ment

ment

ordrywar

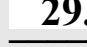

29.0

$\longrightarrow$

82. Bank / Bridge Protection:

\begin{tabular}{|l|l|l|l|l|l|l|l|l|}
\hline Location & USLWW & USRWW & LABUT & RABUT & LB & RB & DSLWW & DSRWW \\
\hline Type & give & ear- & no & inin & und & g & babl & ut \\
\hline Condition & s & ance & und & g. & erm & was & y & $\mathbf{0 . 5}$ \\
\hline Extent & app & of & erm & The & inin & pro & abo & feet \\
\hline
\end{tabular}

Bank / Bridge protection types: 0- absent; 1- < 12 inches; 2- < 36 inches; 3- < 48 inches; 4- < 60 inches;

5- wall / artificial levee

Bank / Bridge protection conditions: 1-good; 2- slumped; 3- eroded; 4- failed

Protection extent: 1- entire base length; 2- US end; 3- DS end; 4- other 
83. Wingwall and protection comments (eg. undermined penetration, unusual scour processes, etc.):

at most prior to the settlement. The concrete deterioration at the base of both abutments makes it difficult to decipher exposure depths.

$\mathbf{Y}$
$\mathbf{1}$
$\mathbf{1}$
$\mathbf{0}$
$\mathbf{Y}$
$\mathbf{1}$
$\mathbf{0}$

\section{Piers:}

84. Are there piers? _ _ (Y or if $N$ type ctrl-n pr)

\begin{tabular}{|l|r|r|r|r|l|l|l|}
\hline \multirow{2}{*}{$\begin{array}{l}85 . \\
\text { Pier no. }\end{array}$} & \multicolumn{3}{|c|}{ width (w) feet } & \multicolumn{3}{c|}{ elevation (e) feet } \\
\cline { 2 - 8 } & w1 & w2 & w3 & e@w1 & e@w2 & e@w3 \\
\hline Pier 1 & & $\mathbf{7 . 5}$ & $\mathbf{7 . 5}$ & $\mathbf{6 5 . 0}$ & $\mathbf{3 0 . 0}$ & $\mathbf{3 5 . 0}$ \\
\hline Pier 2 & $\mathbf{8 . 5}$ & $\mathbf{9 . 0}$ & - & $\mathbf{8 5 . 0}$ & - & - \\
\hline Pier 3 & - & - & - & - & - & - \\
\hline Pier 4 & - & - & - & - & - & - \\
-
\end{tabular}

\begin{tabular}{|l|l|l|l|l|}
\hline Level 1 Pier Descr. & \multicolumn{1}{|c|}{1} & \multicolumn{1}{|c|}{2} & 3 & \multicolumn{1}{|c|}{4} \\
\hline 86. Location (BF) & Y & 2 & - & dete- \\
\hline 87. Type & $\mathbf{1}$ & $\mathbf{1}$ & - & rio- \\
\hline 88. Material & $\mathbf{2}$ & $\mathbf{1}$ & - & ratio \\
\hline 89. Shape & $\mathbf{0}$ & $\mathbf{2}$ & - & $\mathbf{n}$ \\
\hline 90. Inclined? & $\mathbf{1 . 5}$ & $\mathbf{2}$ & $\mathbf{0}$ & and \\
\hline 91. Attack $\angle$ (BF) & $\mathbf{Y}$ & $\mathbf{1}$ & - & sub- \\
\hline 92. Pushed & $\mathbf{1}$ & $\mathbf{2}$ & - & sequ \\
\hline 93. Length (feet) & - & - & - & - \\
\hline 94. \# of piles & $\mathbf{3}$ & $\mathbf{0}$ & $\mathbf{0}$ & ent \\
\hline 95. Cross-members & $\mathbf{0}$ & - & - & ero- \\
\hline 96. Scour Condition & $\mathbf{2 . 0}$ & - & - & sion \\
\hline 97. Scour depth & $\mathbf{5}$ & - & Con- & has \\
\hline 98. Exposure depth & $\mathbf{1}$ & - & crete & occu \\
\hline
\end{tabular}

LFP, LTB, LB, MCL, MCM, MCR, RB, RTB, RFP

1- Solid pier, 2- column, 3- bent

1- Wood; 2- concrete; 3- metal; 4- stone

1- Round; 2- Square; 3- Pointed

Y-yes; $N$ - no

$L B$ or $R B$

0- none; 1- laterals; 2- diagonals; 3- both

0- not evident; 1- evident (comment);

2- footing exposed; 3- piling exposed;

4- undermined footing; 5- settled; 6-failed 
99. Pier comments (eg. undermined penetration, protection and protection extent, unusual scour processes, etc.):

rred at the downstream end of the upstream left wingwall at the corner where the wingwall meets the abutment wall. Protection is in place where the footing's concrete has eroded. Rangepole penetration under the upstream left wingwall and left abutment from footer erosion is between 0.5 and 1 foot. The deterioration has affected mostly the footing as opposed to the abutment wall. The abutment wall concrete appears in good condition. The downstream right wingwall footing is about 1.5 feet thick. The concrete footing of the downstream left wingwall and the downstream end of the left abutment has deteriorated and eroded away completely except for some fragments of concrete that remain on the streambed adjacent to the walls presumably from the wingwall / abutment footings.

100.

\section{E. Downstream Channel Assessment}

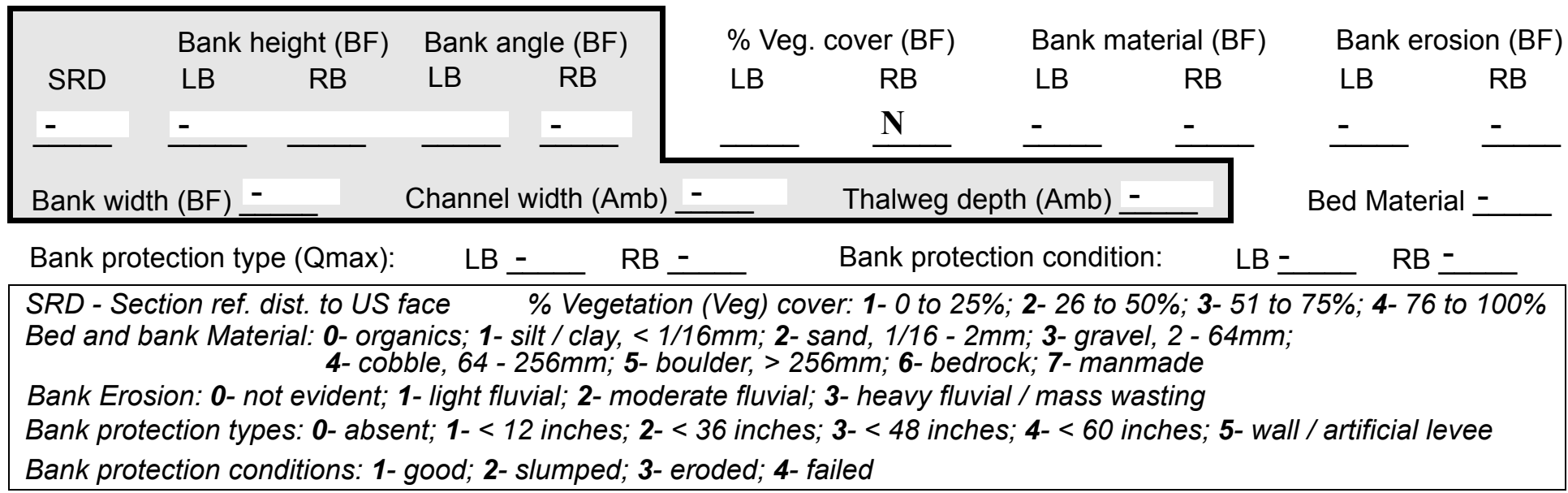

Comments (eg. bank material variation, minor inflows, protection extent, etc.):

$-$

-

$-$

$-$

$-$

$-$

101. Is a drop structure present? _ ( $Y$ or $N$, if $N$ type ctrl-n ds) 102. Distance: ___ feet 103. Drop: - _ feet 104. Structure material: __ (1- steel sheet pile; 2- wood pile; 3- concrete; 4- other) 105. Drop structure comments (eg. downstream scour depth):

$-$

$-$ 
106. Point/Side bar present? (Y or $N$. if $N$ type ctrl-n pb)Mid-bar distance:

Mid-bar width: -

Point bar extent: feet -

(US, UB, DS) to feet (US, UB, DS) positioned $\%$ LB to $\% R B$ Material:

Point or side bar comments (Circle Point or Side; note additional bars, material variation, status, etc.):

Is a cut-bank present? - (Y or if $N$ type ctrl-n $c b)$ Where? - _ (LB or RB) Mid-bank distance: NO Cut bank extent: $\underline{\text { PIE feet }}$ RS (US, UB, DS) to feet (US, UB, DS)

Bank damage: (1- eroded and/or creep; 2- slip failure; 3- block failure)

Cut bank comments (eg. additional cut banks, protection condition, etc.):

Is channel scour present? Scour dimensions: Length $\mathbf{4}$ Width 4 (Y or if $N$ type ctrl-n cs)

Mid-scour distance:

Scour comments (eg. additional scour areas, local scouring process, etc.):

2

4

0

$\mathbf{0}$

Are there major confluences? - (Yor if $N$ type ctrl-n $m c)$

Confluence 1: Distance The Enters on righ ( $L B$ or $R B)$

Enters on mat ( $L B$ or $R B)$

Positioned 3

$\%$ LB to 1 $\%$ RB

Confluence comments (eg. confluence name):

is a composite type with equal thicknesses of soil on top and alluvial, somewhat bouldery gravelly sand on the bottom. The soil appears more cohesive and less erodible as roots and the soil layer are clearly overhanging

\section{F. Geomorphic Channel Assessment}

107. Stage of reach evolution the

1- Constructed

2- Stable

3- Aggraded

4- Degraded

5- Laterally unstable

6- Vertically and laterally unstable 
108. Evolution comments (Channel evolution not considering bridge effects; See HEC-20, Figure 1 for geomorphic descriptors):

underlying material. When the overhanging soil layer does fail and the material slumps into the channel, the block is washed away perhaps quickly by rather swift currents, particularly along the right bank near the impact zone. 


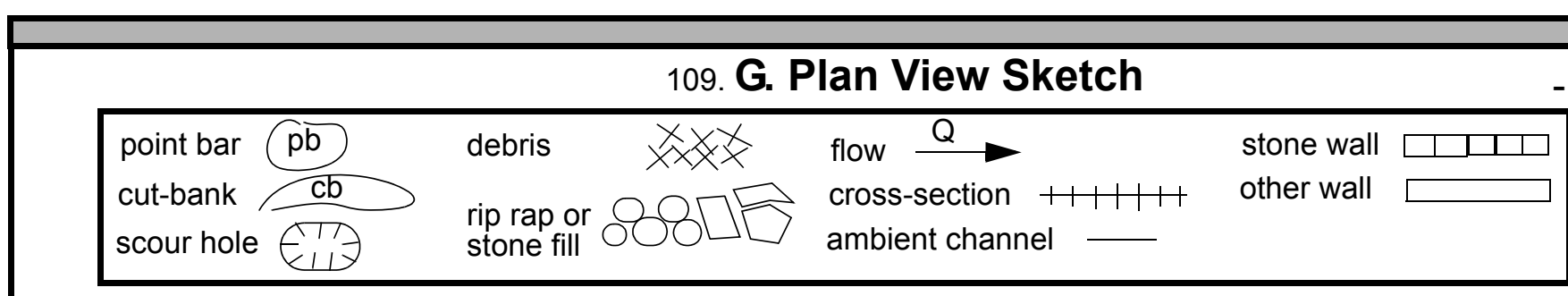


APPENDIX F:

SCOUR COMPUTATIONS 


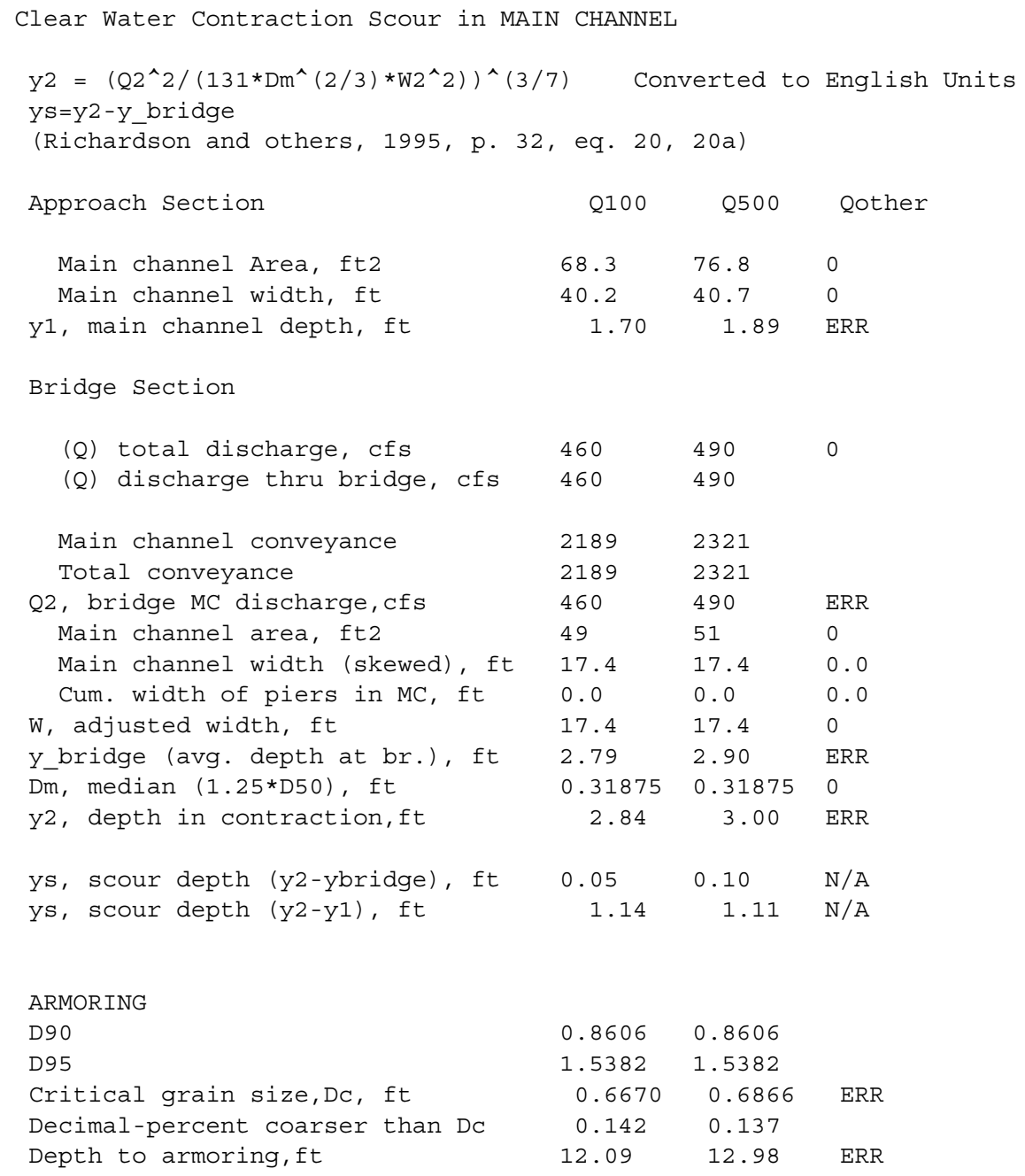




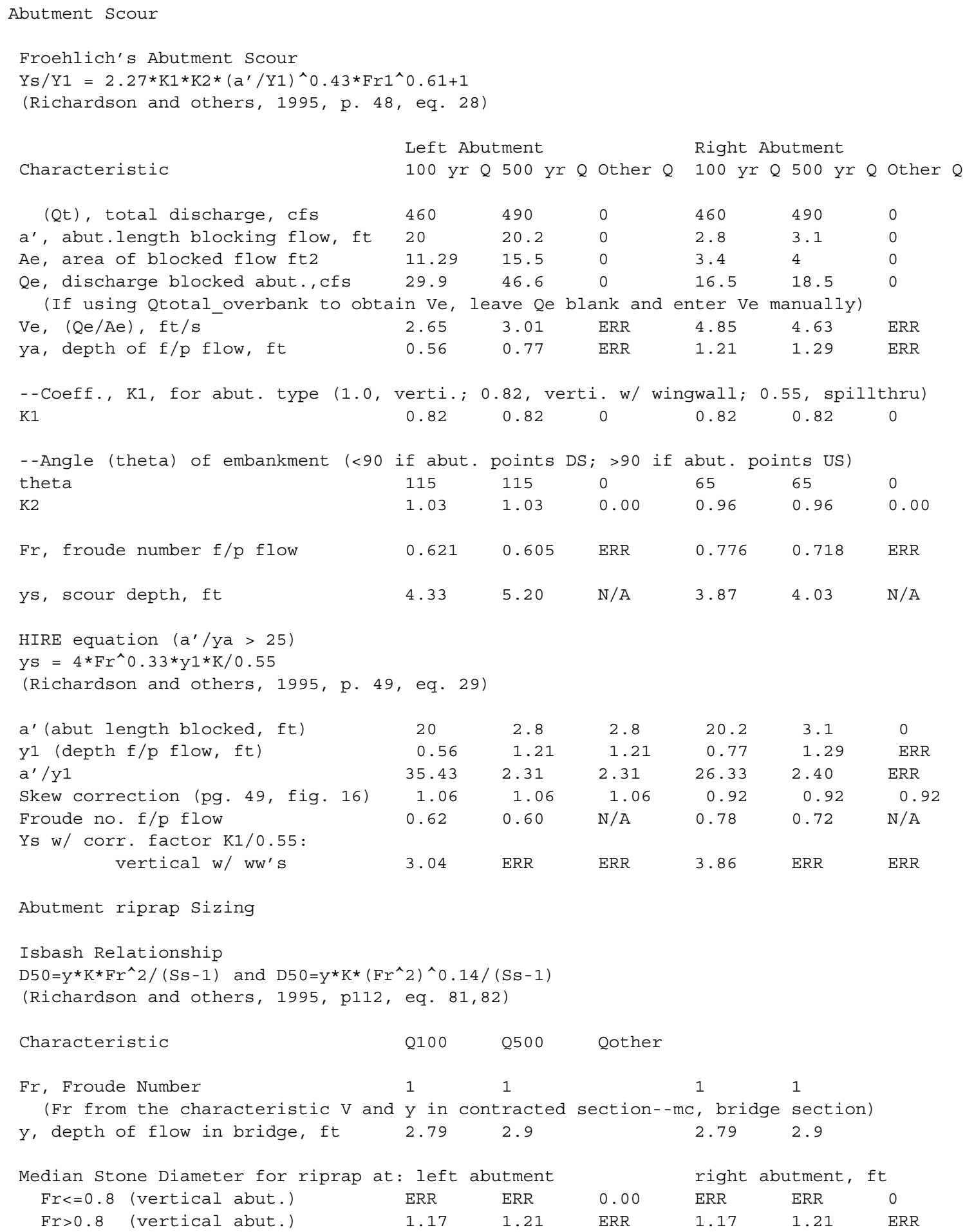

